Article

\title{
Fluorescent Biaryl Uracils with C5-Dihydro- and Quinazolinone Heterocyclic Appendages in PNA
}

\author{
Ali Heidari ${ }^{1,+} \oplus$, Arash Ghorbani-Choghamarani ${ }^{2, *}$, Maryam Hajjami ${ }^{2}{ }^{-1}$ and \\ Robert H. E. Hudson $1, *$ (D) \\ 1 Department of Chemistry, The University of Western Ontario, London, ON N6A 5B7, Canada; \\ aheidar2@uwo.ca \\ 2 Department of Chemistry, Faculty of Science, Ilam University, Ilam 69315516, Iran; mhajjami@yahoo.com \\ * Correspondence: a.ghorbani@ilam.ac.ir (A.G.-C.); rhhudson@uwo.ca (R.H.E.H.); Tel.: +1-519-661-2111 \\ (R.H.E.H.); Fax: +1-519-661-3022 (R.H.E.H.) \\ † Current address: Institut für Physiologische Chemie und Pathobiochemie, Universitätsklinikum Münster, \\ Waldeyerstr. 15, 48149 Münster, Germany.
}

Academic Editor: Katherine Seley-Radtke

Received: 4 April 2020; Accepted: 20 April 2020; Published: 24 April 2020

check for updates

\begin{abstract}
There has been much effort to exploit fluorescence techniques in the detection of nucleic acids. Canonical nucleic acids are essentially nonfluorescent; however, the modification of the nucleobase has proved to be a fruitful way to engender fluorescence. Much of the chemistry used to prepare modified nucleobases relies on expensive transition metal catalysts. In this work, we describe the synthesis of biaryl quinazolinone-uracil nucleobase analogs prepared by the condensation of anthranilamide derivatives and 5-formyluracil using inexpensive copper salts. A selection of modified nucleobases were prepared, and the effect of methoxy- or nitro- group substitution on the photophysical properties was examined. Both the dihydroquinazolinone and quinazolinone modified uracils have much larger molar absorptivity $(\sim 4-8 \times)$ than natural uracil and produce modest blue fluorescence. The quinazolinone-modified uracils display higher quantum yields than the corresponding dihydroquinazolinones and also show temperature and viscosity dependent emission consistent with molecular rotor behavior. Peptide nucleic acid (PNA) monomers possessing quinazolinone modified uracils were prepared and incorporated into oligomers. In the sequence context examined, the nitro-substituted, methoxy-substituted and unmodified quinazolinone inserts resulted in a stabilization $\left(\Delta \mathrm{T}_{\mathrm{m}}=+4.0 /\right.$ insert; $+2.0 /$ insert; $+1.0 /$ insert, respectively) relative to control PNA sequence upon hybridization to complementary DNA. All three derivatives responded to hybridization by the "turn-on" of fluorescence intensity by ca. 3-to-4 fold and may find use as probes for complementary DNA sequences.
\end{abstract}

Keywords: peptide nucleic acid; nucleobase-modified PNA; solid-phase synthesis; dihydroquinazolinone; quinazolinone; quinazolinone based nucleobase; fluorescent probes

\section{Introduction}

Since the 1980s, much effort has been devoted to exploiting fluorescence techniques in the detection and study of nucleic acids. While aromatic-based amino acids (phenylalanine, tyrosine and tryptophan) possess intrinsic fluorescence, natural nucleic acids are essentially nonfluorescent $[1,2]$. In order to facilitate studies with nucleic acids, structurally modified oligonucleotides that incorporate a luminophore have been pursued aggressively. There is a wide range of methods used to produce fluorescent oligonucleotides, for example, by the substitution of a structural feature-such as the nucleobase-with a fluorophore, or by appending a chromophore to the nucleobase or sugar-phosphate backbone [3]. An especially fruitful approach has been to expand the nucleobase by ring fusion or 
to extend the conjugation through an ethylene or ethyne bridge and/or by direct coupling to another aromatic moiety via a biaryl bond [4,5]; these routes overwhelmingly employ precious metal catalysts. The 5-heteroaromatic uracils are attractive targets as modified nucleobases since they have been shown to retain their hydrogen bonding ability to the complementary nucleobases but have the potential to be fluorescent and possess molecular rotor properties that enable them to be "turn on" probes of nucleic acid structure [6,7] (Figure 1).

a)<smiles>Cn1ccc(=O)[nH]c1=O</smiles>

b)<smiles>Cn1c(=O)[nH]c(=O)c2ccccc21</smiles>

c)<smiles>Cn1cc(C#Cc2ccccc2)c(=O)[nH]c1=O</smiles>

d)<smiles>Cn1cc(-c2ccccc2)c(=O)[nH]c1=O</smiles>

e)<smiles>[X]c1cn(CC(C)C)c(=O)[nH]c1=O</smiles>

Figure 1. Selected examples of uracil nucleobase (a) structural modifications: ring fusion (b), extension of conjugation (c), biaryl (d) and heterocycle biaryl (e) derivatives. $\mathrm{Ph}=$ phenyl.

Peptide nucleic acid (PNA) is an oligonucleotide analog capable of forming highly stable complexes with its target nucleic acid [8]. One of the attractive features of PNA is its hybridization properties-a combination of high affinity and high selectivity [9] that enable its use as a probe molecule [10]. Numerous modified nucleobases have been incorporated into PNA [11]; two notable brightly fluorescent cytosine analogs are 3,5-diaza-4-oxophenothiazine (tC) [12] and phenylpyrrolocytosine (PhpC) [13], each involving multi-step ring construction syntheses (Figure 2).
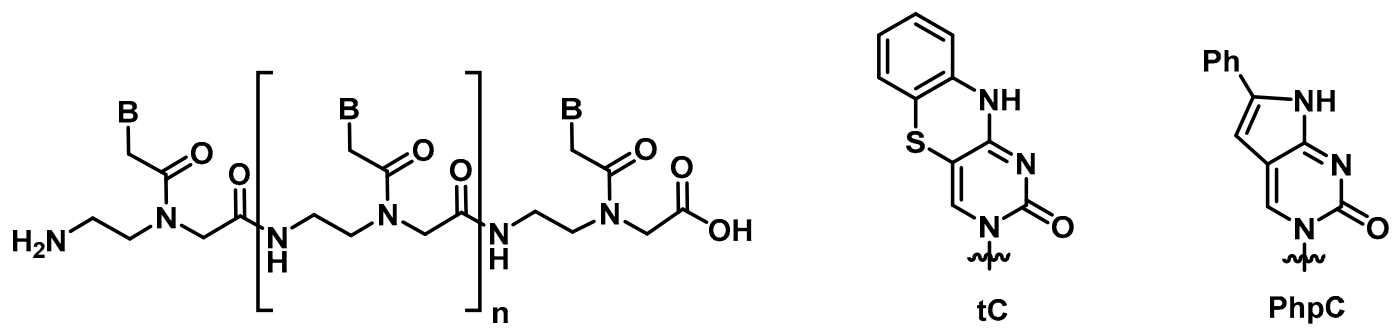

Figure 2. Generic structure of a peptide nucleic acid oligomer (PNA, left) and two examples of fluorescent nucleobases. $\mathrm{B}=$ nucleobase, $\mathrm{Ph}=$ phenyl.

With interest in simplifying the synthesis of a uracil with a biaryl-type bond to a heterocycle, we turned to the single-pot condensation of 5-formyluracil derivatives [14] with substituted 2-aminobenzamides [15]. This route has the advantage of ease of synthesis that permitted the rapid preparation and evaluation of a selection of substituted quinazolinone-uracil derivatives.

\section{Results}

\subsection{Synthesis of Dihydroquinazolinone-Based Uracil Scaffold}

Herein, we describe a simple and convenient route for the synthesis of dihydroquinazolinone-uracil and quinazolinone-uracil scaffolds (Scheme 1), as well as an evaluation of their basic photophysical properties. The synthesis of the both the dihydroquinazolinone- and quinazolinone-uracils started with 5-formyluracil (1), accessed from 5-hydroxymethyluracil as previously described [14]. Next, 5-formyluracil (1) was alkylated under standard conditions with tert-butyl bromoacetate to give tert-butyl (5-formyluracil-1-yl)acetate (2) with high yield (Scheme 1). 
<smiles>O=c1[nH]cc(CO)c(=O)[nH]1</smiles><smiles>[R]c1cc(N)c(C(=O)O)cc1[R]</smiles><smiles>O=Cc1c[nH]c(=O)[nH]c1=O</smiles>

1) $\mathrm{Et}_{3} \mathrm{~N}$

2) tBu-bromoacetate<smiles>[R16]</smiles>
$87 \%$

1<smiles>[R]c1cc(N)c(C(N)=O)cc1[R]</smiles>

$3 \mathrm{R}_{1}=-\mathrm{H}, \mathrm{R}_{2}=-\mathrm{OMe}: 58 \%$

$4 \mathrm{R}_{1}=-\mathrm{H}, \mathrm{R}_{2}=-\mathrm{NO}_{2}: 48 \%$

$5 \mathrm{R}_{1}=-\mathrm{OMe}, \mathrm{R}_{2}=-\mathrm{H}: 50 \%$

$6 \mathrm{R}_{1}=-\mathrm{NO}_{2}, \mathrm{R}_{2}=-\mathrm{H}: 80 \%$

$\mathrm{R}_{1}=-\mathrm{H}, \mathrm{R}_{2}=-\mathrm{H}$, commercial<smiles>CC(C)(C)OC(=O)Cn1cc(C=O)c(=O)[nH]c1=O</smiles>
2, $\mathrm{Cu}\left(\mathrm{NO}_{3}\right)_{2}, \mathrm{EtOH}$,
reflux, $2 \mathrm{~h}$

$7 R_{1}=-H, R_{2}=-H: 80 \%$

$8 \mathrm{R}_{1}=-\mathrm{H}, \mathrm{R}_{2}=-\mathrm{NO}_{2}: 42 \%$

$9 \mathrm{R}_{1}=-\mathrm{NO}_{2}, \mathrm{R}_{2}=-\mathrm{H}: 38 \%$

$10 \mathrm{R}_{1}=-\mathrm{OMe}, \mathrm{R}_{2}=-\mathrm{H}: 13 \%$

$11 \mathrm{R}_{1}=-\mathrm{H}, \mathrm{R}_{2}=-\mathrm{OMe}: 40 \%$

Scheme 1. Synthesis of modified quinazolinone-based uracil scaffolds. 4-HO-TEMPO = 4-hydroxy-2,2,6,6-tetramethylpiperidin-1-oxyl; DABCO = (1,4-diazabicyclo[2.2.2]octane).

In order to examine the effect of electron-withdrawing and electron-donating groups on the fluorescent properties of dihydroquinazolinone and quinazolinone compounds, methoxy- and nitro-substituted 2-aminobenzamide compounds were synthesized from commercially available 2-aminobenzoic acids (Scheme 1). The best yields of the 2-aminobenzamides (3-6) were achieved by performing their synthesis in two steps, i.e., the isolation of the isatoic anhydride intermediate after treatment with triphosgene and then doing the ammonolysis at a lower temperature. Subsequently, the 5 -formyluracil (2) was condensed with the various 2-aminobenzamide compounds using copper (II) nitrate catalysis [15] to give substituted dihydroquinazolinone compounds (7-11). Compounds 7-11 were oxidized in high yield to the corresponding quinazolinones $\mathbf{1 2 - 1 6}$, under optimized conditions, vide infra.

\subsection{Synthesis of Quinazolinone-Based Uracil Scaffolds}

Substituted quinazolines have been synthesized by a number of methods, including the condensation of 2-aminobenzylamines with aldehydes using copper (II) nitrate in refluxing ethanol followed by subsequent treatment with a stoichiometric oxidant [16]. It has been observed in cases that the Lewis acid catalyst for the condensation may also promote oxidation. Catalytic aerobic oxidation $(\mathrm{CuCl} / \mathrm{DABCO} / 4-\mathrm{HO}-\mathrm{TEMPO})$ has been developed for the preparation of substituted quinazolines [17], and we used this as a starting point to determine the optimal conditions for the quinazolinone-uracils of interest (Scheme 2). 

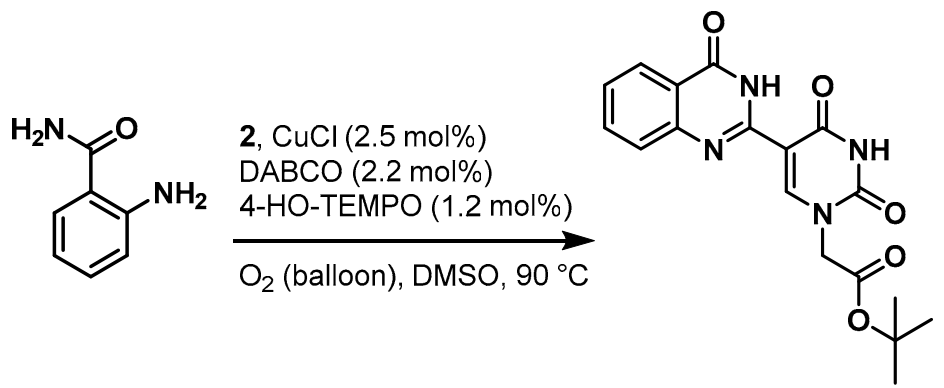

Scheme 2. $\mathrm{CuCl} / \mathrm{DABCO} / 4-\mathrm{HO}-\mathrm{TEMPO}$-catalyzed one-pot aerobic oxidative synthesis of quinazolinone modified uracil.

We investigated the optimal conditions for the reaction of commercially available anthranilamide $\left(\mathrm{R}_{1}=\mathrm{H}, \mathrm{R}_{2}=\mathrm{H}\right)$ (1 equiv) with N1-alkylated-5-formyluracil 2 (1 equiv). Firstly, the two starting materials were allowed to condense in situ, and then 4-hydroxy-2,2,6,6-tetramethylpiperidin-1-oxyl (4-HO-TEMPO) (0.2 equiv) was added as the catalyst, and the reaction system was charged with an oxygen atmosphere (balloon) [18]. The target molecule 12 was obtained, but with poor yield due to presumed decomposition of the dihydroquinazolinone intermediate (Table 1, entry 1). To our delight, the reaction was dramatically improved when $\mathrm{CuCl}$ was used in combination with a monodentate $N$-containing ligand such as $\mathrm{Et}_{3} \mathrm{~N}$, DABCO (1,4-diazabicyclo[2.2.2]octane), or DMAP (4-dimethylaminopyridine) (Table 1, entries 4-8). Entry seven demonstrates the need for an oxygen atmosphere for high conversions. The optimized conditions, (Table 1, entry 8) were also used for the oxidation of dihydroquinazolinones 7-11 to quinazolinones 12-16, respectively (Scheme 1).

Table 1. Optimization of the Catalytic Aerobic Oxidative Synthesis of Quinazolinone ${ }^{\mathbf{a}}$.

\begin{tabular}{cccccc}
\hline Entry & Copper & Ligand & TEMPO & Solvent & Yield (\%) \\
\hline $\mathbf{1}$ & - & - & $4-\mathrm{HO}$ & toluene & 32 \\
$\mathbf{2}$ & $\mathrm{CuBr}$ & - & $4-\mathrm{HO}$ & $\mathrm{DMF}$ & 22 \\
$\mathbf{3}$ & $\mathrm{CuCl}$ & - & $4-\mathrm{HO}$ & $\mathrm{DMF}$ & 43 \\
$\mathbf{4}$ & $\mathrm{CuCl}$ & $\mathrm{NEt}_{3}$ & $4-\mathrm{HO}$ & $\mathrm{CH}_{3} \mathrm{CN}$ & 62 \\
$\mathbf{5}$ & $\mathrm{CuCl}$ & $\mathrm{NEt}_{3}$ & $4-\mathrm{HO}$ & $\mathrm{CH}_{3} \mathrm{CN}$ & 80 \\
$\mathbf{6}$ & $\mathrm{CuCl}$ & $\mathrm{DMAP}$ & $4-\mathrm{HO}$ & $\mathrm{DMSO}$ & 86 \\
$\mathbf{7}$ & $\mathrm{CuCl}$ & $\mathrm{DABCO}$ & $4-\mathrm{HO}$ & $\mathrm{DMSO}$ & $12^{\mathrm{b}}$ \\
$\mathbf{8}$ & $\mathrm{CuCl}$ & DABCO & $4-\mathrm{HO}$ & DMSO & 96
\end{tabular}

\footnotetext{
a Anthranilamide $(1.0 \mathrm{mmol})$ and 5-formyluracil derivative $2(1.0 \mathrm{mmol})$ were dissolved in solvent $(8 \mathrm{~mL})$ in a $25 \mathrm{~mL}$ flask, and the mixture was stirred at $80{ }^{\circ} \mathrm{C}$ until the condensation completed (about $\left.2 \mathrm{~h}\right)$. Then, copper salts (0.025 $\mathrm{mmol})$, ligand $(0.022 \mathrm{mmol})$ and 4-HO-TEMPO $(0.012 \mathrm{mmol})$ were added to the reaction mixture, and stirring was continued at $90^{\circ} \mathrm{C}$ under oxygen until the anthranilamide was consumed completely, as monitored by thin layer

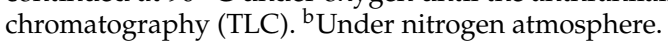

\subsection{Photophysical Properties}

UV-Vis spectra and fluorescence measurements of compounds 7-16 have been made in different solvents in order to characterize their basic photophysical properties (Tables 2 and 3). Determinations of UV-vis absorption molar extinction coefficients $(\varepsilon)$ were made only in DMSO due to limited solubility. Overall, the values generally indicate that the quantum yield in ethanol is greater than that in other solvents for dihydroquinazolinone compounds (Table 2). Additionally, the emission is bathochromically shifted in less polar solvents (THF) versus polar solvents (EtOH). However, since dihydroquinazolinone compounds (7-11) were only very weakly emissive, they were not pursued further for use in PNA monomers or oligomers. 
Table 2. Photophysical properties ${ }^{a}$ of dihydroquinazolinone compounds 7-11.

\begin{tabular}{cccccc}
\hline Compound \# & $\lambda_{\max }(\mathbf{n m})$, DMSO & $\varepsilon\left(\frac{\mathbf{L}}{\mathbf{m o l} \cdot \mathbf{c m}}\right)$, DMSO & $\boldsymbol{\Phi}^{\mathbf{c}}{ }_{\text {(EtOH) }}$ & $\boldsymbol{\Phi}_{(\text {DMSO) }}$ & $\boldsymbol{\Phi}_{(\text {THF })}$ \\
\hline $\mathbf{7}^{\mathrm{b}}$ & 341 & 68,000 & $0.015(412)$ & $0.002(428)$ & $0.001(441)$ \\
$\mathbf{9}^{\mathrm{b}}$ & 417 & 65,500 & $0.008(417)$ & $0.003(436)$ & $0.001(452)$ \\
$\mathbf{1 0}^{\mathbf{1 1}}$ & 417 & 65,500 & $0.007(417)$ & $0.001(436)$ & $0.001(452)$ \\
& 321 & 39,100 & $0.014(386)$ & $0.003(412)$ & $0.003(455)$ \\
\hline
\end{tabular}

a The quantum yields were determined using emission wavelengths between 340 and $640 \mathrm{~nm}$, with an excitation wavelength of $325 \mathrm{~nm} .{ }^{\mathbf{b}}$ Excitation wavelength at $310 \mathrm{~nm} .{ }^{c} \lambda_{\max }$ emission, in nanometers, in parentheses.

Table 3. Photophysical properties ${ }^{\text {a }}$ of quinazolinone compounds 12-16.

\begin{tabular}{|c|c|c|c|c|c|c|c|}
\hline Compound \# & $\lambda_{\text {max }^{\prime}} b_{(n m)}$ & $\varepsilon\left(\frac{\mathrm{L}}{\mathrm{mol} \cdot \mathrm{cm}}\right)^{\mathrm{c}}$ & $\mathrm{T}\left({ }^{\circ} \mathrm{C}\right)$ & $\Phi^{c}{ }_{(\mathrm{EtOH})}$ & $\Phi_{\text {(DMSO) }}$ & $\Phi_{\text {(THF) }}$ & $\Phi_{\text {(Glycerol) }}$ \\
\hline 12 & 331 & 36,400 & $\begin{array}{l}60 \\
23 \\
15\end{array}$ & $\begin{array}{c}0.006 \\
0.012(401) \\
0.038\end{array}$ & $\begin{array}{c}0.002 \\
0.006(415)\end{array}$ & $0.008(440)$ & $\begin{array}{c}0.031 \\
0.083(422)\end{array}$ \\
\hline $13^{d}$ & 417 & 65,500 & $\begin{array}{l}60 \\
23 \\
15\end{array}$ & NA * & $\begin{array}{c}0.001 \\
0.003(434)\end{array}$ & $0.004(453)$ & $0.024(394)$ \\
\hline $14^{\mathrm{d}}$ & 417 & 65,500 & $\begin{array}{l}60 \\
23 \\
15\end{array}$ & NA * & $\begin{array}{c}<0.001 \\
0.001(434)\end{array}$ & $0.003(453)$ & 0.018 (394) \\
\hline 15 & 340 & 39,100 & $\begin{array}{l}60 \\
23 \\
15\end{array}$ & $\begin{array}{c}0.006 \\
0.023(432) \\
0.041\end{array}$ & $\begin{array}{c}0.007 \\
0.009(437)\end{array}$ & $0.016(458)$ & $\begin{array}{c}0.059 \\
0.076(452)\end{array}$ \\
\hline 16 & 340 & 39,100 & $\begin{array}{l}60 \\
23 \\
15\end{array}$ & $\begin{array}{c}0.017 \\
0.035(432) \\
0.076\end{array}$ & $\begin{array}{c}0.008 \\
0.011(437)\end{array}$ & $0.019(458)$ & $\begin{array}{c}0.062 \\
0.106(452)\end{array}$ \\
\hline
\end{tabular}

${ }^{a}$ the quantum yields were determined using emission wavelengths between 340 and $640 \mathrm{~nm}$, with an excitation wavelength of $330 \mathrm{~nm} ;{ }^{b} \lambda_{\max }=$ lowest energy absorbance band in UV/vis spectrum, in DMSO; ${ }^{c}$ calculated based on absorption in DMSO; ${ }^{d}$ excitation wavelength $=310 \mathrm{~nm} ;{ }^{*}$ compound was not sufficiently soluble in ethanol.

The planarity and rigidity of the molecular structure plays a major role in determining the fluorescence properties of aromatic compounds [19]. Thus, the dehydrogenation of dihydroquinazolinone compounds 7-11 (Schemes 1 and 2) was done to increase conjugation and molecular rigidity. It was envisioned that the quinazolinone structure would favor being coplanar with the uracil by an intramolecular hydrogen bond (Figure 3a,b) and this would potentially benefit the fluorescence quantum yield. Computational studies of the two structures (Figure $3 a, b$ ) was done at the Hartree-Foch $6-31+\mathrm{G}^{*}$ level to determine the most favorable tautomer and the minimum energy conformation. The calculated structures show that the planes defined by the dihydroquinazolinone and uracil have a severe twist $\left(\sim 70^{\circ}\right)$ about the biaryl bond (shown in red, Figure 3a), whereas the quinazolinone and uracil exists in a coplanar geometry with a hydrogen bond (predicted length $1.99 \AA$ ) between the amide proton and C4-oxygen. 

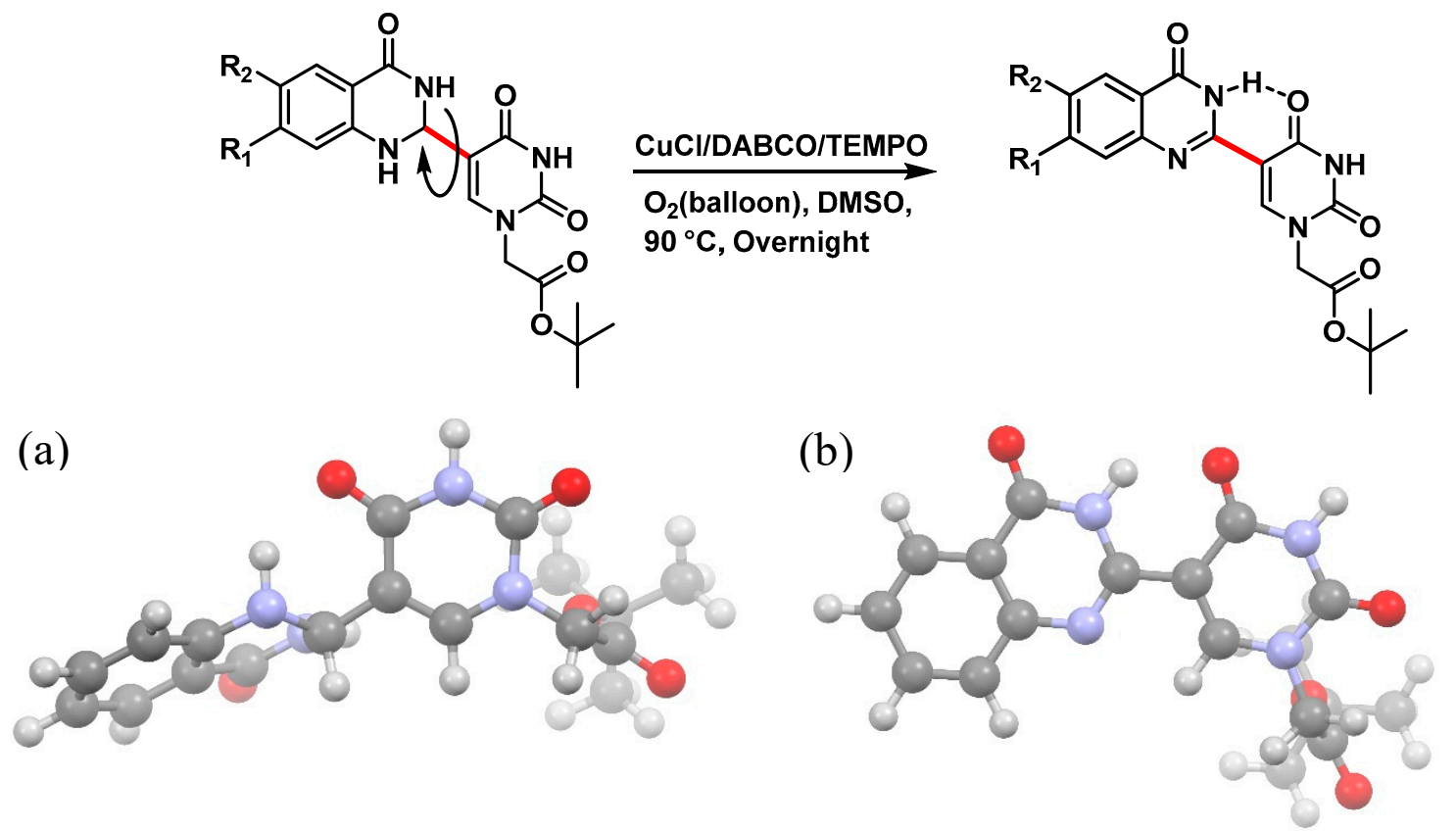

Figure 3. Top: chemical structures and dehydrogenation conditions. Bottom: molecular representations of the structures at minimum energy states; most energetically favorable tautomer for (a) dihydroquinazolinone (b) and quinazolinone.

The trends in the fluorescence quantum yields largely support this notion, i.e., that the quinazolinone-uracils (12-16) are more emissive than the dihydroquinzolinone congeners (7-11) (Table 3). However, the nitro-substituted quinazolinone compounds also tended to be less soluble, and measurements could not be made in ethanol. We also investigated the effects of temperature and environmental viscosity (ethanol versus glycerol) on the fluorescent properties (Table 3). The increase in fluorescence quantum yield when moving from ethanol (or other less viscous solvents) to the viscous glycerol is consistent with a reduced loss of excited state energy through intramolecular rotations, particularly with respect to the biaryl bond. Further evidence of the molecular rotor behavior is shown by the increase in quantum yield as the temperature is lowered.

\subsection{PNA Monomer Synthesis and Oligomerization}

The quinazolinone-based uracil scaffolds were designed to retain the usual hydrogen bonding ability to a complementary nucleobase. In order to test the ability of these modified bases to respond to hybridization, i.e., the transition from a relatively unstructured single-stranded probe to the more highly structured environment of duplex, a selection of PNA monomers were prepared. A priori, it was not known how quinazolinone ring substitution would affect hybridization (stacking) interactions or fluorescence properties in the context of oligomers; thus, the unsubstituted quinazolinone-based uracil scaffold (12), the nitro-substituted quinazolinone (13) and the methoxy-substituted quinzaolinone (16) were chosen to prepare PNA monomers (Scheme 3). 

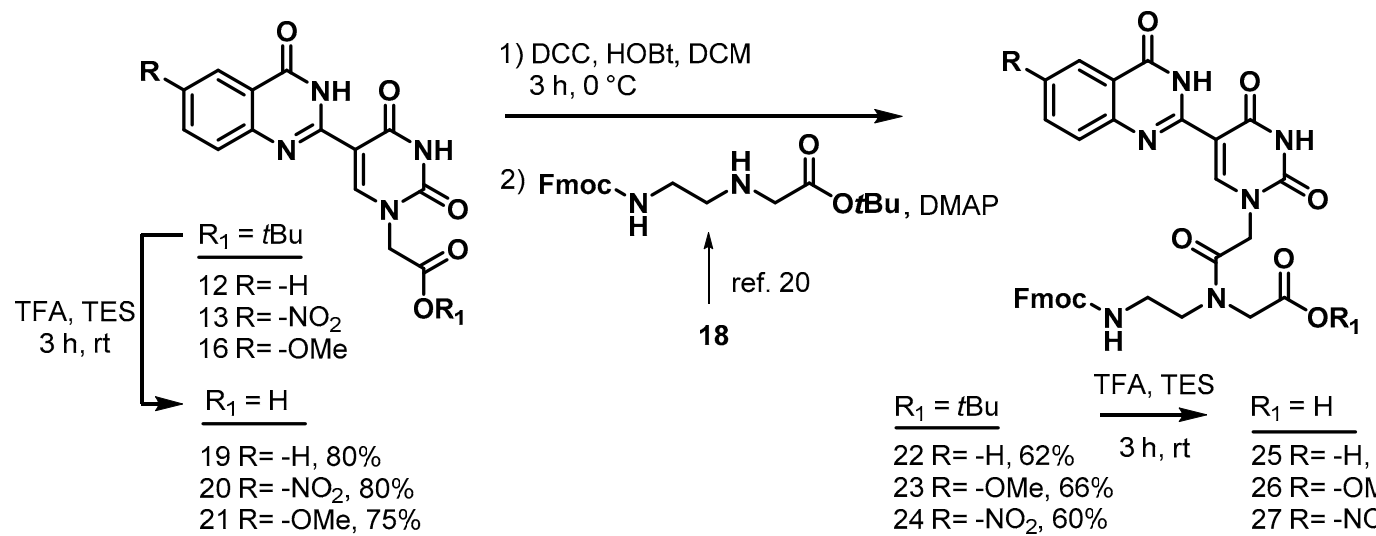

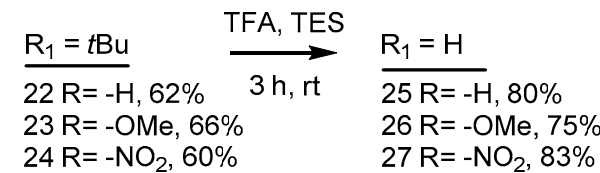

Scheme 3. Synthesis of quinazolinone-uracil PNA monomers.

Proceeding to monomer synthesis and oligomerization, the tert-butyl esters of the quinazolinone based uracil scaffolds $(12,13$ and 16) were converted to the free acids $(19,20$ and 21$)$ by acidolysis with trifluoroacetic acid in the presence of triethylsilane. The free base of the tert-butyl-Fmoc-based aminoethylglycine backbone was liberated from the hydrochloride salt (18) immediately prior to use [20]. The quinazolinone-based nucleobase acetic acid was then converted to the active ester, in situ, by treatment with a solution of hydroxybenzotriazole $(\mathrm{HOBt})$ and dicyclohexylcarbodiimide (DCC). The active ester of the nucleobase derivative was then coupled to the tert-butyl-Fmoc-based aminoethylglycine backbone in the presence of DMAP to give the monomer esters with usual yields. Finally, the monomers $(25,26$ and 27$)$ were produced by the acidolysis of the tert-butyl esters, as previously done. The monomers were characterized using ${ }^{1} \mathrm{H}$ and ${ }^{13} \mathrm{C} \mathrm{NMR}$ spectroscopy, as is usual for PNA monomer signals, indicating the presence of rotomers (see supplemental data). Additionally, the compounds were identified by high-resolution mass spectrometry (HRMS).

With monomers 25, 26 and 27 in hand, PNA sequences were prepared by automated peptide synthesis (Table 1). The three PNA monomers performed well, with no significant difference between them and commercially available standard PNA monomers (Table S1 and Page S5-S9). As is commonly done, all of the oligomers were constructed with a C-terminal lysine in order to impart water solubility. Once the oligomers were in hand, thermal stability $\left(\mathrm{T}_{\mathrm{m}}\right)$ analysis with complementary DNA and PNA was undertaken.

The unmodified PNA control sequence hybridization with complementary PNA showed excellent agreement with our previous report $\left(67.5^{\circ} \mathrm{C}\right)$ [20]. The unmodified quinazolinone showed a slight decrease in the thermal stability of the duplex compared to that for an unmodified PNA $\left(\sim \Delta \mathrm{Tm}=-1.0^{\circ} \mathrm{C}\right.$ per insert), which may be useful in pseudocomplementary PNA applications as a fluorescent reporter, although this requires further study. On the other hand, both the nitro- and methoxy-substituted quinazolinones showed an increase in $\mathrm{T}_{\mathrm{m}}$ values when hybridized to the PNA strand. (Table 4). Similar results were observed for hybridization with complementary (underlined) DNA (5'-AGTGATCTACCT-3'): the nitro-substituted quinazolinone had the greatest stabilizing effect $\left(\Delta \mathrm{T}_{\mathrm{m}}=+4.0^{\circ} \mathrm{C}\right.$ per insert $)$; next was methoxy-substituted quinazolinone $\left(\Delta \mathrm{T}_{\mathrm{m}}=+2.0^{\circ} \mathrm{C}\right.$ per insert $)$, while the unsubstituted quinazolinone gave a slight stabilization $\left(\Delta \mathrm{T}_{\mathrm{m}}=+1.0^{\circ} \mathrm{C}\right.$ per insert). 
Table 4. Thermal stabilities $\left(\mathrm{T}_{\mathrm{m}}\right)$ of double-stranded PNA (dsPNA) and heteroduplex complexes.

\begin{tabular}{|c|c|c|c|c|}
\hline \multirow[b]{2}{*}{ Sequence $(\mathrm{N} \rightarrow \mathrm{C})$} & \multicolumn{2}{|c|}{ vs. DNA * } & \multicolumn{2}{|c|}{ vs. PNA ${ }^{\dagger}$} \\
\hline & $\mathrm{T}_{\mathrm{m}}\left({ }^{\circ} \mathrm{C}\right)$ & $\Delta \mathrm{T}_{\mathrm{m}}$ & $\mathrm{T}_{\mathrm{m}}\left({ }^{\circ} \mathrm{C}\right)$ & $\Delta \mathrm{T}_{\mathrm{m}}$ \\
\hline H-Lys-GTAGATCACT-Lys-NH ${ }_{2}$ & 54.5 & & 67.5 & \\
\hline H-GTAGA QUCACT-Lys-NH ${ }_{2}$ & 55.5 & +1.0 & 66.5 & -1.0 \\
\hline H-GTAGA ${ }^{\mathrm{Q}} \mathrm{U}^{(\mathrm{NO} 2)}$ CACT-Lys-NH & 58.5 & +4.0 & 72.5 & +5.0 \\
\hline H-GTAGA ${ }^{\mathrm{Q}}{ }^{(\mathrm{OMe})}$ CACT-Lys-NH & 56.5 & +2.0 & 70.5 & +3.0 \\
\hline
\end{tabular}

PNA oligomers are listed from the pseudo $5^{\prime}$-terminus to the pseudo $3^{\prime}$-end. Lys $=$ L-lysine, ${ }^{\mathrm{Q}} \mathbf{U}^{(\mathrm{NO} 2)}=$ 6-nitroquinazolinone uracil, ${ }^{Q} \mathbf{U}^{(\mathrm{OMe})}=6$-methoxyquinazolinone uracil, ${ }^{\mathrm{Q}} \mathbf{U}=$ quinazolinone uracil PNA residues. * The complementary DNA oligomer 5'-AGTGATCTAC-3' was used. ' ${ }^{\dagger}$ The complementary PNA oligomer H-Lys-AGTGATCTAC-Lys- $\mathrm{NH}_{2}$ was used. Temperature-dependent UV spectra at $2 \mu \mathrm{M}$ strand concentration, each in $100 \mathrm{mM}$ sodium phosphate buffer, $\mathrm{pH}=7.0$.

\subsection{Fluorescence Properties Analysis}

The steady-state fluorescence excitation and emission spectra were measured for single-stranded PNA ${ }^{Q} \mathbf{U},{ }^{Q} \mathbf{U}^{(\mathrm{OMe})}$ and ${ }^{\mathrm{Q}} \mathbf{U}^{(\mathrm{NO} 2)}$ and heteroduplexes with fully complementary DNA (Figure $4 \mathrm{a}-\mathrm{c}$ ). Trends similar to those in the fluorescence studies at the submonomer level were observed, that is, the nitro-substituted quinazolinone uracil scaffold shows the weakest fluorescent intensity while the methoxy-substituted has the highest. However, each of the nucleobase fluorophores displayed a "turn-on" response of approximately 3-to-4 fold to hybrid formation. Interestingly, the $\mathbf{Q}^{\mathbf{U}^{(\mathrm{NO} 2)}}$ oligomer displayed the largest fluorescence "turn-on" response, without a notable change in the peak wavelength. The $\mathrm{Q} \mathbf{U}^{(\mathrm{NO} 2)}$ oligomer also shows the greatest increase in the stability of the complex as measured by the $\mathrm{T}_{\mathrm{m}}$ value. A plausible explanation is that the ${ }^{\mathrm{Q}} \mathbf{U}^{(\mathrm{NO} 2)}$ oligomer has relatively stronger stacking interactions, leading to both a more stabilized hybrid and a relatively more rigid structure, providing a slightly better fluorescence turn-on effect. The more electron-rich parent quinazolinone and 6-methoxyquinazolinone both displayed a hypsochromic shift in the emission for the hybrid, which likely reflects the change in the polarity of the environment of the fluorophore. Nonetheless, all three fluorophores showed marked increases in emission upon hybridization, which is consistent with increased rigidity in the duplex and the molecular rotor behavior of biaryl-chromophores. The degree of fluorescence intensity in quinazolinone uracil scaffolds appears to weakly correlate with the helix-stabilizing ability of the base. The most stable heteroduplex occurs with ${ }^{\mathrm{Q}} \mathbf{U}^{(\mathrm{NO} 2)}$-modified PNA.

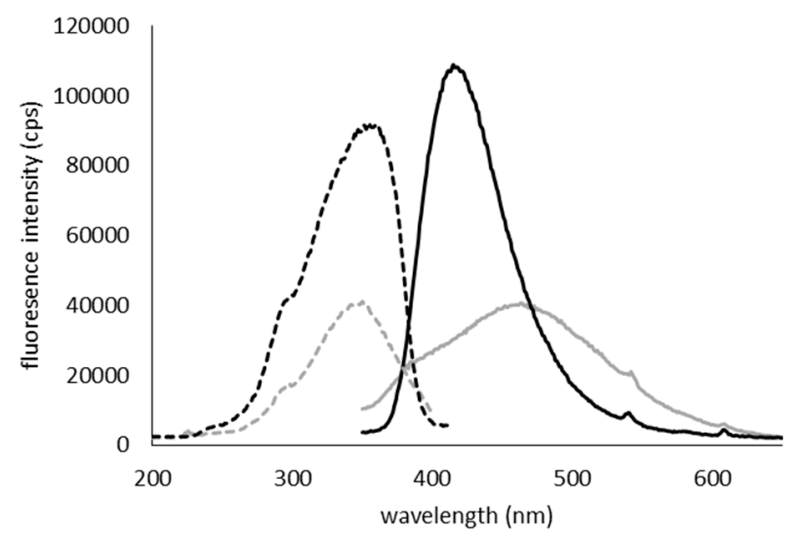

(a)

Figure 4. Cont. 


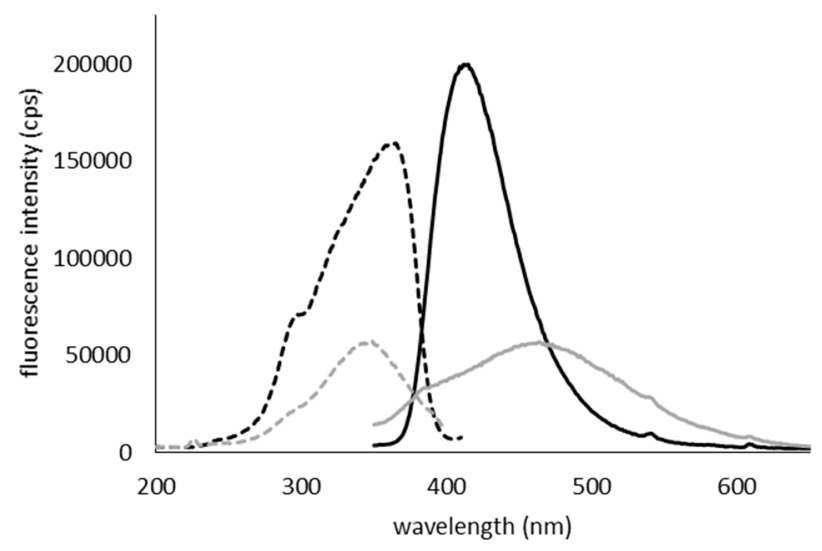

(b)

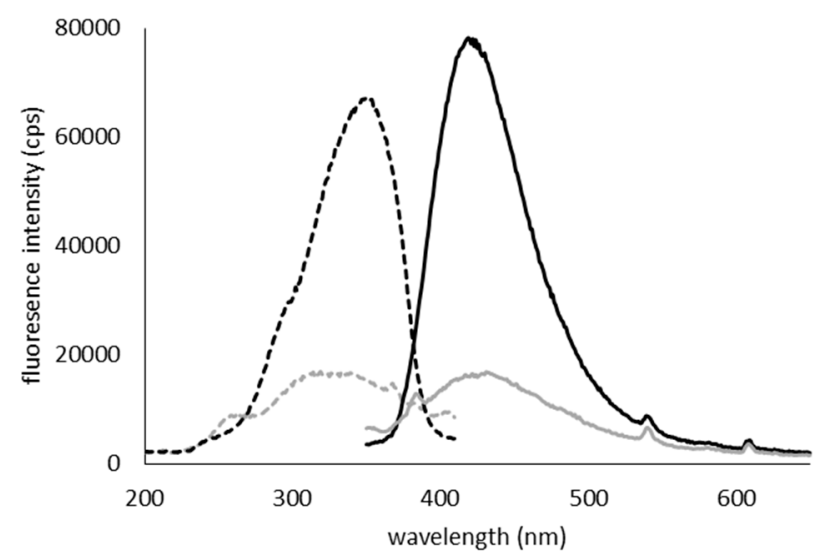

(c)

Figure 4. Fluorescence excitation spectra (broken lines) and emission spectra (solid lines) for the single-stranded probe containing PNAs (grey lines) and for the heteroduplexes formed with complementary PNA (black lines) at $2 \mu \mathrm{M}$ strand concentration; $100 \mathrm{mM}$ sodium phosphate

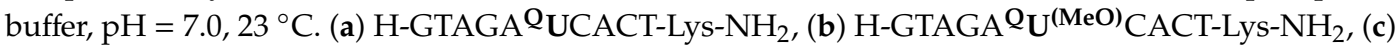
H-GTAGA ${ }^{\mathrm{Q}} \mathbf{U}^{\left({ }^{(N O 2)} \text { CACT-Lys-NH }\right.}$. $^{\circ}$

\section{Materials and Methods}

\subsection{Synthesis and Characterization}

\section{5-Formyluracil (1)}<smiles>O=Cc1c[nH]c(=O)[nH]c1=O</smiles>

5-Hydroxymethyluracil $(4.0 \mathrm{~g}, 28 \mathrm{mmol})$, was dissolved in $100 \mathrm{~mL}$ water by heating to $75^{\circ} \mathrm{C}$. The solution was allowed to cool to $40{ }^{\circ} \mathrm{C}$, and then $\mathrm{K}_{2} \mathrm{~S}_{2} \mathrm{O}_{8}(13.6 \mathrm{~g}, 49.6 \mathrm{mmol})$ and $\mathrm{AgNO}_{3}(0.14 \mathrm{~g}$, $0.8 \mathrm{mmol}$ ) were added and the product began to slowly precipitate. The reaction was stirred for $15 \mathrm{~min}$ at $35^{\circ} \mathrm{C}$ and then for $10 \mathrm{~min}$ at room temperature. The mixture was held at $4{ }^{\circ} \mathrm{C}$ for $1 \mathrm{~h}$, after which time the product was collected by filtration, washed with cold water and dried to yield $\mathbf{1}(3.2 \mathrm{~g}, 22.7 \mathrm{mmol}$, $84 \%)$ as a white solid. The spectra matched the literature values [14]. ${ }^{1} \mathrm{H}$ NMR (400 MHz, DMSO- $\left.d_{6}\right) \delta$ 
$\left.\left.11.96(\mathrm{~s}, 1 \mathrm{H}), 11.50(\mathrm{~s}, 1 \mathrm{H}), 9.74(\mathrm{~s}, 1 \mathrm{H}), 8.13(\mathrm{~s}, 1 \mathrm{H}) .{ }^{13} \mathrm{C}\right\}{ }^{1} \mathrm{H}\right\} \mathrm{NMR}\left(101 \mathrm{MHz}, \mathrm{DMSO}-d_{6}\right) \delta$ 186.9, 162.9, $150.9,149.7,110.6$.

tert-Butyl (5-formyluracil-1-yl)acetate (2)<smiles>CC(C)OC(=O)Cn1cc(C=O)c(=O)[nH]c1=O</smiles>

5-Formyluracil 1 (2.0 g, $14.3 \mathrm{mmol})$ was added to $50 \mathrm{~mL}$ dry dimethylformamide (DMF), heated to $40{ }^{\circ} \mathrm{C}$ to dissolve and then allowed to cool to room temperature. Triethylamine ( $\mathrm{NEt}_{3}, 2.0 \mathrm{~mL}$, $14.3 \mathrm{mmol})$ was added to the solution in one portion. tert-Butyl bromoacetate $(2.11 \mathrm{~mL}, 14.3 \mathrm{mmol})$ was added dropwise to the stirred mixture over $30 \mathrm{~min}$ and then stirring was continued for $24 \mathrm{~h}$ under an $\mathrm{N}_{2}$ atmosphere. The solvent was removed in vacuo and the residue was extracted with ethyl acetate and water. The organic layer was washed with brine, dried by $\mathrm{Na}_{2} \mathrm{SO}_{4}$ and concentrated in vacuo to give 2 as a pure, white solid product $(3.16 \mathrm{~g}, 12.43 \mathrm{mmol}, 87 \%)$. Spectroscopic analysis conformed to previous reports [21]. ${ }^{1} \mathrm{H}$ NMR $\left(400 \mathrm{MHz}, \mathrm{DMSO}-d_{6}\right) \delta 11.92(\mathrm{~s}, 1 \mathrm{H}), 9.79(\mathrm{~s}, 1 \mathrm{H}), 8.51(\mathrm{~s}, 1 \mathrm{H}), 4.56(\mathrm{~s}$, $\left.2 \mathrm{H}), 4.02(\mathrm{q}, J=7.1 \mathrm{~Hz}, 1 \mathrm{H}), 1.98(\mathrm{~s}, 1 \mathrm{H}), 1.42(\mathrm{~s}, 12 \mathrm{H}) .{ }^{13} \mathrm{C}{ }^{1} \mathrm{H}\right\} \mathrm{NMR}\left(101 \mathrm{MHz}, \mathrm{DMSO}-d_{6}\right) \delta 186.8$, 167.0, 164.1, 163.7, 162.7, 154.1, 152.4, 150.4, 110.7, 102.6, 82.8, 60.3, 50.5, 50.4, 28.0, 27.9, 14.5.

\section{2-Amino-5-methoxybenzamide (3)}<smiles>COc1ccc(N)c(C(N)=O)c1</smiles>

2-Amino-5-methoxybenzoic acid $(0.35 \mathrm{~g}, 2.5 \mathrm{mmol})$ was dissolved in $4 \mathrm{~mL}$ tetrahydrofuran (THF) and heated to $60^{\circ} \mathrm{C}$, and then triphosgene $(0.25 \mathrm{~g}, 0.84 \mathrm{mmol})$ was added and the reaction was stirred for $10 \mathrm{~h}$. The reaction progress was monitored by TLC analysis. The solution cooled down to room temperature, and the isatoic anhydride intermediate was filtered and collected. Cold $1 \mathrm{~N}$ ammonia was added to the collected intermediate, and the mixture was stirred for $24 \mathrm{~h}$ at $4{ }^{\circ} \mathrm{C}$. To the crude solution were added $10 \mathrm{~mL}$ of EtOAc/Hexanes (1:1) mixture, and the resulting precipitate was filtered and washed sequentially with water and diethyl ether to give $0.240 \mathrm{~g}(1.4 \mathrm{mmol}, 58 \%)$ of Compound 3 as a brown solid. Spectra matched those reported by the Integrated Spectral Database System of Organic Compounds (AIST, Tokio, Japan). ${ }^{1} \mathrm{H}$ NMR $\left(400 \mathrm{MHz}\right.$, DMSO- $\left.d_{6}\right) \delta 7.75(\mathrm{~s}, 1 \mathrm{H}), 7.10(\mathrm{~d}, J=2.9 \mathrm{~Hz}$, 1H), $\left.\left.7.08(\mathrm{~s}, 1 \mathrm{H}), 6.84(\mathrm{dd}, J=8.9,2.9 \mathrm{~Hz}, 1 \mathrm{H}), 6.64(\mathrm{~d}, J=8.9 \mathrm{~Hz}, 1 \mathrm{H}), 6.12(\mathrm{~s}, 2 \mathrm{H}), 3.68(\mathrm{~s}, 3 \mathrm{H}) .{ }^{13} \mathrm{C}\right\}{ }^{1} \mathrm{H}\right\}$ NMR $\left(101 \mathrm{MHz}\right.$, DMSO- $\left.d_{6}\right) \delta 171.4,149.6,144.9,120.3,118.2,114.4,112.9,56.0$.

\section{2-Amino-5-nitrobenzamide (4)}<smiles>NC(=O)c1cc([N+](=O)[O-])ccc1N</smiles>

2-Amino-5-nitrobenzoic acid $(0.785 \mathrm{~g}, 4.5 \mathrm{mmol})$ was dissolved in $10 \mathrm{~mL}$ of THF and heated to $60{ }^{\circ} \mathrm{C}$, triphosgene $(0.45 \mathrm{~g}, 1.5 \mathrm{mmol})$ was added and the reaction was stirred for $10 \mathrm{~h}$. The reaction progress was monitored by TLC analysis. The solution was cooled to room temperature, and the isatoic anhydride intermediate was filtered and collected. Cold $1 \mathrm{~N}$ ammonia was added to the collected intermediate, and the mixture was stirred for $24 \mathrm{~h}$ at $4{ }^{\circ} \mathrm{C}$. The turbid solution was filtered and washed with water and ether to give $0.430 \mathrm{~g}(2.3 \mathrm{mmol}, 48 \%)$ of Compound 4 as a yellow solid. Spectra matched those reported by the Integrated Spectral Database System of Organic Compounds (AIST, Japan). ${ }^{1} \mathrm{H}$ NMR (400 MHz, DMSO- $\left.d_{6}\right) \delta 8.56(\mathrm{~d}, J=2.6 \mathrm{~Hz}, 1 \mathrm{H}), 8.21(\mathrm{~s}, 1 \mathrm{H}), 8.02(\mathrm{dd}, J=9.2,2.6 \mathrm{~Hz}, 1 \mathrm{H}), 7.90$ 
$\left.\left.(\mathrm{s}, 2 \mathrm{H}), 7.41(\mathrm{~s}, 1 \mathrm{H}), 6.80(\mathrm{~d}, J=9.2 \mathrm{~Hz}, 1 \mathrm{H}) .{ }^{13} \mathrm{C}\right\}{ }^{1} \mathrm{H}\right\} \mathrm{NMR}\left(101 \mathrm{MHz}\right.$, DMSO- $\left.d_{6}\right) \delta 170.1,156.2,135.2$, $128.0,126.9,116.4,112.5$.

\section{2-Amino-4-methoxybenzamide (5)}<smiles>COc1ccc(C(N)=O)c(N)c1</smiles>

2-Amino-4-methoxybenzoic acid $(0.501 \mathrm{~g}, 3.0 \mathrm{mmol})$ was dissolved in $6 \mathrm{~mL}$ THF and heated to $60{ }^{\circ} \mathrm{C}$, triphosgene $(0.3 \mathrm{~g}, 1 \mathrm{mmol})$ was added and the reaction was stirred for $10 \mathrm{~h}$. The reaction progress was monitored by TLC analysis. Cold $1 \mathrm{~N}$ ammonia was added to the collected intermediate, and the mixture was stirred for $24 \mathrm{~h}$ at $4{ }^{\circ} \mathrm{C}$. The turbid solution was filtered and washed with water and ether to give $0.25 \mathrm{~g}(1.5 \mathrm{mmol}, 50 \%)$ of Compound 5 as a white solid. Spectra matched those reported by the Integrated Spectral Database System of Organic Compounds (AIST, Japan). ${ }^{1} \mathrm{H}$ NMR $\left(400 \mathrm{MHz}, \mathrm{DMSO}-d_{6}\right) \delta 7.49(\mathrm{~d}, J=8.8 \mathrm{~Hz}, 1 \mathrm{H}), 6.74(\mathrm{~s}, 2 \mathrm{H}), 6.20(\mathrm{~d}, J=2.6 \mathrm{~Hz}, 1 \mathrm{H}), 6.07(\mathrm{dd}, J=8.8$, $2.6 \mathrm{~Hz}, 1 \mathrm{H}), 3.70(\mathrm{~s}, 3 \mathrm{H})$.

\section{2-Amino-4-nitrobenzamide (6)}<smiles>NC(=O)c1ccc([N+](=O)[O-])cc1N</smiles>

2-Amino-4-nitrobenzoic acid $(0.549 \mathrm{~g}, 3.0 \mathrm{mmol})$ was dissolved in $6 \mathrm{~mL}$ THF and, heated to $60^{\circ} \mathrm{C}$, triphosgene $(0.3 \mathrm{~g}, 1 \mathrm{mmol})$ was added, the reaction was stirred for $5 \mathrm{~h}$ and the reaction progress was monitored by TLC. The solution was cooled to room temperature, and the isatoic anhydride intermediate was filtered and collected. Cold $1 \mathrm{~N}$ ammonia was added to the collected intermediate, and the mixture was stirred for $24 \mathrm{~h}$ at $4{ }^{\circ} \mathrm{C}$. The turbid solution was filtered and washed with water and diethyl ether to give $0.430 \mathrm{~g}(2.3 \mathrm{mmol}, 80 \%)$ of Compound 6 as an orange solid. Spectra matched those reported by the Integrated Spectral Database System of Organic Compounds (AIST, Japan). ${ }^{1} \mathrm{H}$ NMR $\left(400 \mathrm{MHz}, \mathrm{DMSO}-d_{6}\right) \delta 8.03(\mathrm{~s}, 1 \mathrm{H}), 7.74(\mathrm{~d}, J=8.6 \mathrm{~Hz}, 1 \mathrm{H}), 7.57(\mathrm{~d}, J=2.4 \mathrm{~Hz}, 1 \mathrm{H}), 7.46(\mathrm{~s}, 1 \mathrm{H})$, $7.25(\mathrm{dd}, J=8.6,2.4 \mathrm{~Hz}, 1 \mathrm{H}), 7.02(\mathrm{~s}, 2 \mathrm{H})$.

\section{tert-Butyl 2-(5-(4-oxo-1,2,3,4-tetrahydroquinazolin-2-yl)uracil-1-yl)acetate (7)}<smiles>CC(C)(C)OC(=O)Cn1cc(C2NC(=O)c3ccccc3N2)c(=O)[nH]c1=O</smiles>

To a solution of $0.50 \mathrm{~g}(2.0 \mathrm{mmol})$ of 2 dissolved in $10 \mathrm{~mL}$ of reflux ethanol were added $36 \mathrm{mg}$ $(0.13 \mathrm{mmol})$ of $\mathrm{Cu}\left(\mathrm{NO}_{3}\right)_{2} \cdot 3 \mathrm{H}_{2} \mathrm{O}$ and $0.14 \mathrm{~g}(1.0 \mathrm{mmol})$ of 2-aminobenzamide. The reaction mixture was stirred for $2 \mathrm{~h}$ and analyzed by TLC. The solution was cooled to room temperature, and the resulting precipitate was filtered and washed sequentially with $\mathrm{EtOH}$ and $\mathrm{MeOH}$ to give $7(0.298 \mathrm{~g}, 0.8 \mathrm{mmol}$, $80 \%$ ) as a white solid. ${ }^{1} \mathrm{H}$ NMR $\left(400 \mathrm{MHz}\right.$, DMSO- $\left.d_{6}\right) \delta 11.62(\mathrm{~s}, 1 \mathrm{H}), 7.95(\mathrm{~d}, J=1.8 \mathrm{~Hz}, 1 \mathrm{H}), 7.82(\mathrm{~s}$, $1 \mathrm{H}), 7.62(\mathrm{dd}, J=7.8,1.6 \mathrm{~Hz}, 1 \mathrm{H}), 7.25(\mathrm{ddd}, J=8.5,7.2,1.7 \mathrm{~Hz}, 1 \mathrm{H}), 6.78(\mathrm{~d}, J=8.1 \mathrm{~Hz}, 1 \mathrm{H}), 6.75-6.66$ $\left.\left.(\mathrm{m}, 2 \mathrm{H}), 5.68(\mathrm{~d}, J=2.0 \mathrm{~Hz}, 1 \mathrm{H}), 4.48(\mathrm{~s}, 2 \mathrm{H}), 1.40(\mathrm{~s}, 9 \mathrm{H}) .{ }^{13} \mathrm{C}\right\}{ }^{1} \mathrm{H}\right\}$ NMR $\left(101 \mathrm{MHz}\right.$, DMSO- $\left.d_{6}\right) \delta$ 167.5, 163.9, 163.3, 150.9, 148.2, 144.5, 133.7, 127.9, 117.9, 115.3, 112.9, 82.2, 60.4, 50.1, 28.1. HRMS (ESI/Q-TOF) $m / z:[\mathrm{M}]^{+}$calculated for $\mathrm{C}_{18} \mathrm{H}_{20} \mathrm{~N}_{4} \mathrm{O}_{5}, 372.1434$; found, 372.1428. 
tert-Butyl 2-(5-(6-nitro-4-oxo-1,2,3,4-tetrahydroquinazolin-2-yl)uracil-1-yl) acetate (8)<smiles>CC(C)(C)OC(=O)CN1C=C(C2NC(=O)c3cc([N+](=O)[O-])ccc3N2)NC(=O)N1</smiles>

To a solution of $0.50 \mathrm{~g}$ ( $2.0 \mathrm{mmol})$ of 2 dissolved in $10 \mathrm{~mL}$ of refluxing ethanol, $36.2 \mathrm{mg}(0.15 \mathrm{mmol})$ of $\mathrm{Cu}\left(\mathrm{NO}_{3}\right)_{2} \cdot 3 \mathrm{H}_{2} \mathrm{O}$ and $0.18 \mathrm{~g}(1 \mathrm{mmol})$ of 2-amino-5-nitrobenzamide were added, and the reaction mixture was stirred for $2 \mathrm{~h}$ and monitored by TLC. The solution was cooled to room temperature, and the resulting precipitate was filtered and washed with $\mathrm{EtOH}$ and $\mathrm{MeOH}$ to give 8 (176 mg, $0.42 \mathrm{mmol}$, $42 \%)$ as a yellow solid. ${ }^{1} \mathrm{H}$ NMR $\left(400 \mathrm{MHz}\right.$, DMSO- $\left.d_{6}\right) \delta 11.67(\mathrm{~s}, 1 \mathrm{H}), 8.41(\mathrm{dd}, J=8.3,2.4 \mathrm{~Hz}, 2 \mathrm{H})$, $8.30(\mathrm{~s}, 1 \mathrm{H}), 8.09(\mathrm{dd}, J=9.1,2.8 \mathrm{~Hz}, 1 \mathrm{H}), 7.81(\mathrm{~s}, 1 \mathrm{H}), 6.84(\mathrm{~d}, J=9.1 \mathrm{~Hz}, 1 \mathrm{H}), 5.85(\mathrm{t}, J=2.1 \mathrm{~Hz}, 1 \mathrm{H})$, $\left.4.47(\mathrm{~s}, 2 \mathrm{H}), 1.39(\mathrm{~s}, 9 \mathrm{H}) .{ }^{13} \mathrm{C}{ }^{1} \mathrm{H}\right\}$ NMR (101 MHz, DMSO-d $\left.d_{6}\right) \delta 167.7,162.9,161.6,152.4,150.9,144.4$, 137.5, 129.2, 124.5, 114.9, 113.0, 112.9, 82.3, 61.0, 49.9, 28.1. HRMS (ESI/Q-TOF) $m / z$ : [M] ${ }^{+}$calculated for $\mathrm{C}_{18} \mathrm{H}_{19} \mathrm{~N}_{5} \mathrm{O}_{7}$, 417.1284; found, 417.1271.

tert-Butyl 2-(5-(7-nitro-4-oxo-1,2,3,4-tetrahydroquinazolin-2-yl)uracil-1-yl)acetate (9)<smiles>CC(C)(C)OC(=O)CN1C=C(C2NC(=O)c3ccc([N+](=O)[O-])cc3N2)NC(=O)N1</smiles>

To a solution of $0.50 \mathrm{~g}(2.0 \mathrm{mmol})$ of 2 dissolved in $10 \mathrm{~mL}$ of refluxing ethanol, $36.2 \mathrm{mg}(0.15 \mathrm{mmol})$ of $\mathrm{Cu}\left(\mathrm{NO}_{3}\right)_{2} \cdot 3 \mathrm{H}_{2} \mathrm{O}$ and $0.18 \mathrm{~g}(1 \mathrm{mmol})$ of 2-amino-4-nitrobenzamide were added, and the reaction mixture was stirred for $2 \mathrm{~h}$ and monitored by TLC. The solution was cooled down to room temperature, and the resulting precipitate was filtered and washed with $\mathrm{EtOH}$ and $\mathrm{MeOH}$ to give $9(160 \mathrm{mg}$, $0.38 \mathrm{mmol}, 38 \%)$ as a yellow solid. ${ }^{1} \mathrm{H}$ NMR $\left(600 \mathrm{MHz}, \mathrm{DMSO}-d_{6}\right) \delta 11.62(\mathrm{~s}, 1 \mathrm{H}), 8.34(\mathrm{~s}, 1 \mathrm{H}), 7.79(\mathrm{~d}, J$ $=8.5 \mathrm{~Hz}, 1 \mathrm{H}), 7.74(\mathrm{~s}, 1 \mathrm{H}), 7.59(\mathrm{~d}, J=2.3 \mathrm{~Hz}, 1 \mathrm{H}), 7.43-7.37(\mathrm{~m}, 2 \mathrm{H}), 5.73(\mathrm{~s}, 1 \mathrm{H}), 4.43(\mathrm{~s}, 2 \mathrm{H}), 1.34(\mathrm{~s}$, 9H). $\left.\left.{ }^{13} \mathrm{C}\right\}{ }^{1} \mathrm{H}\right\}$ NMR (101 MHz, DMSO-d $\left.d_{6}\right) \delta 166.5,162.9,161.6,152.4,150.9,144.4,137.5,129.2,124.5$, 114.8, 113.0, 112.9, 82.3, 61.0, 49.9, 27.3. HRMS (ESI/Q-TOF) $m / z:[\mathrm{M}]^{+}$calculated for $\mathrm{C}_{18} \mathrm{H}_{19} \mathrm{~N}_{5} \mathrm{O}_{7}$, 417.1284; found, 417.1270.

tert-Butyl 2-(5-(7-methoxy-4-oxo-1,2,3,4-tetrahydroquinazolin-2-yl)uracil-1-yl)acetate (10)<smiles>COc1ccc2c(c1)NC(c1cn(CC(=O)OC(C)(C)C)c(=O)[nH]c1=O)NC2=O</smiles>

To a solution of $0.25 \mathrm{~g}$ ( $1.0 \mathrm{mmol})$ of 2 dissolved in $10 \mathrm{~mL}$ of refluxing ethanol, $18.1 \mathrm{mg}(0.075 \mathrm{mmol})$ of $\mathrm{Cu}\left(\mathrm{NO}_{3}\right)_{2} \cdot 3 \mathrm{H}_{2} \mathrm{O}$ and $83 \mathrm{mg}(0.5 \mathrm{mmol})$ of 2-amino-4-methoxybenzamide were added, and the reaction mixture was stirred for $10 \mathrm{~h}$ and monitored by TLC. The solution was cooled to room temperature, and the resulting precipitate was filtered and washed with $\mathrm{EtOH}$ and $\mathrm{MeOH}$ to give $\mathbf{1 0}$ 
(51 mg, $0.13 \mathrm{mmol}, 13 \%)$ as a yellow solid. ${ }^{1} \mathrm{H}$ NMR (400 MHz, DMSO-d 6 ) $\delta 12.37(\mathrm{~s}, 1 \mathrm{H}), 12.03(\mathrm{~s}, 1 \mathrm{H})$, $\left.\left.9.02(\mathrm{~s}, 1 \mathrm{H}), 8.02(\mathrm{~d}, J=8.7 \mathrm{~Hz}, 1 \mathrm{H}), 7.12-7.01(\mathrm{~m}, 2 \mathrm{H}), 4.70(\mathrm{~s}, 2 \mathrm{H}), 3.89(\mathrm{~s}, 3 \mathrm{H}), 1.45(\mathrm{~s}, 9 \mathrm{H}) .{ }^{13} \mathrm{C}\right)^{1} \mathrm{H}\right\}$ NMR $\left(101 \mathrm{MHz}, \mathrm{DMSO}-d_{6}\right) \delta 167.2,164.6,164.5,160.1,151.3,150.7,150.1,149.6,128.1,116.1,114.8$, 108.2, 103.2, 82.7, 56.1, 50.7, 28.1. HRMS (ESI/Q-TOF) $m / z:[\mathrm{M}]^{+}$calculated for $\mathrm{C}_{19} \mathrm{H}_{22} \mathrm{~N}_{4} \mathrm{O}_{6}, 402.1539$; found, 402.1536 .

tert-Butyl 2-(5-(6-methoxy-4-oxo-1,2,3,4-tetrahydroquinazolin-2-yl)uracil-1-yl)acetate (11)<smiles>COc1ccc2c(c1)C(=O)NC(c1cn(CC(=O)OC(C)(C)C)c(=O)[nH]c1=O)N2</smiles>

To a solution of $0.25 \mathrm{~g}(1 \mathrm{mmol})$ of 2 dissolved in $10 \mathrm{~mL}$ of refluxing ethanol, $18.1 \mathrm{mg}(0.075 \mathrm{mmol})$ of $\mathrm{Cu}\left(\mathrm{NO}_{3}\right)_{2} \cdot 3 \mathrm{H}_{2} \mathrm{O}$ and $83 \mathrm{mg}(0.5 \mathrm{mmol})$ of 2-amino-5-methoxybenzamide were added, and the reaction mixture was stirred for $4 \mathrm{~h}$ and monitored by TLC. The solution was cooled to room temperature, and the resulting precipitate was filtered and washed with EtOH and $\mathrm{MeOH}$ to give $\mathbf{1 1}(155 \mathrm{mg}, 0.40 \mathrm{mmol}$, $40 \%$ ) as a yellow solid. ${ }^{1} \mathrm{H}$ NMR $\left(400 \mathrm{MHz}, \mathrm{DMSO}-d_{6}\right) \delta 11.61(\mathrm{~s}, 1 \mathrm{H}), 8.00(\mathrm{t}, J=1.8 \mathrm{~Hz}, 1 \mathrm{H}), 7.82(\mathrm{~s}$, $1 \mathrm{H}), 7.16(\mathrm{~d}, J=3.0 \mathrm{~Hz}, 1 \mathrm{H}), 6.93(\mathrm{dd}, J=8.7,3.0 \mathrm{~Hz}, 1 \mathrm{H}), 6.77(\mathrm{~d}, J=8.8 \mathrm{~Hz}, 1 \mathrm{H}), 6.38(\mathrm{~d}, J=1.7 \mathrm{~Hz}$, $\left.\left.1 \mathrm{H}), 5.62(\mathrm{t}, J=1.7 \mathrm{~Hz}, 1 \mathrm{H}), 4.48(\mathrm{~s}, 2 \mathrm{H}), 3.69(\mathrm{~s}, 3 \mathrm{H}), 1.40(\mathrm{~s}, 9 \mathrm{H}) .{ }^{13} \mathrm{C}\right\}{ }^{1} \mathrm{H}\right\} \mathrm{NMR}\left(101 \mathrm{MHz}, \mathrm{DMSO}-d_{6}\right) \delta$ 167.5, 163.9, 163.3, 152.2, 150.9, 144.5, 142.5, 121.8, 116.9, 116.0, 112.7, 110.4, 82.2, 60.6, 55.7, 50.0, 28.1. HRMS (ESI/Q-TOF) m/z: [M] ${ }^{+}$calculated for $\mathrm{C}_{19} \mathrm{H}_{22} \mathrm{~N}_{4} \mathrm{O}_{6}, 402.1539$; found, 402.1537 .

tert-Butyl 2-(5-(4-oxo-3,4-dihydroquinazolin-2-yl)uracil-1-yl)acetate (12)<smiles>CC(C)(C)OC(=O)Cn1cc(-c2nc3ccccc3c(=O)[nH]2)c(=O)[nH]c1=O</smiles>

To a solution of $0.15 \mathrm{~g},(0.4 \mathrm{mmol})$ of 7 fully dissolved in $1 \mathrm{~mL}$ of DMSO at $60{ }^{\circ} \mathrm{C}$ were added $\mathrm{CuCl}$ (1.2 mg, $0.01 \mathrm{mmol}), 4-\mathrm{HO}-\mathrm{TEMPO}(1 \mathrm{mg}, 0.005 \mathrm{mmol})$ and DABCO (1 mg, $0.009 \mathrm{mmol})$. The mixture was stirred at $90{ }^{\circ} \mathrm{C}$ for $18 \mathrm{~h}$ under an atmosphere of $\mathrm{O}_{2}$ (balloon). After the completion of the reaction (monitored by TLC), the reaction was cooled to room temperature and the resulting precipitate was washed with water and ethanol to give the product $12(0.15 \mathrm{~g}, 0.4 \mathrm{mmol}, 100 \%)$ as a white solid. ${ }^{1} \mathrm{H}$ NMR (400 MHz, DMSO-d $) \delta 12.46(\mathrm{~s}, 1 \mathrm{H}), 9.27(\mathrm{~s}, 1 \mathrm{H}), 8.38(\mathrm{~d}, J=7.9 \mathrm{~Hz}, 1 \mathrm{H}), 8.08(\mathrm{t}, J=7.7 \mathrm{~Hz}$, $\left.\left.1 \mathrm{H}), 7.90(\mathrm{~d}, J=8.2 \mathrm{~Hz}, 1 \mathrm{H}), 7.74(\mathrm{t}, J=7.5 \mathrm{~Hz}, 1 \mathrm{H}), 4.96(\mathrm{~s}, 2 \mathrm{H}), 1.71(\mathrm{~s}, 9 \mathrm{H}) .{ }^{13} \mathrm{C}\right\}{ }^{1} \mathrm{H}\right\} \mathrm{NMR}(151 \mathrm{MHz}$, DMSO- $\left.d_{6}\right) \delta 166.8,164.3,150.5,150.0,149.1,134.8,126.4,126.3,121.5,110.0,103.5,82.8,50.8,40.8,40.7$, 40.6, 40.4, 40.3, 40.2, 40.0, 28.2. HRMS (ESI/Q-TOF) $m / z:[\mathrm{M}]^{+}$calculated for $\mathrm{C}_{18} \mathrm{H}_{18} \mathrm{~N}_{4} \mathrm{O}_{5}, 370.1277$; found, 370.1279 .

tert-Butyl 2-(5-(6-nitro-4-oxo-1,4-dihydroquinazolin-2-yl)uracil-1-yl)acetate (13) 
<smiles>CC(C)(C)OC(=O)Cn1cc(-c2nc3ccc([N+](=O)[O-])cc3c(=O)[nH]2)c(=O)[nH]c1=O</smiles>

To a solution of $0.13 \mathrm{~g}(0.31 \mathrm{mmol})$ of 8 in $1 \mathrm{~mL}$ of DMSO dissolved at $60^{\circ} \mathrm{C}$ were added $\mathrm{CuCl}$ ( $2.9 \mathrm{mg}, 0.02 \mathrm{mmol}), 4$-HO-TEMPO ( $2 \mathrm{mg}, 0.012 \mathrm{mmol})$ and DABCO ( $2 \mathrm{mg}, 0.022 \mathrm{mmol})$. The mixture was stirred at $90{ }^{\circ} \mathrm{C}$ overnight under an atmosphere of $\mathrm{O}_{2}$ (balloon). After the completion of the reaction (monitored by TLC), the reaction was cooled to room temperature and the resulting precipitate was washed with water and ethanol to give the product 13 as a yellow solid $(0.13 \mathrm{~g}, 0.31 \mathrm{mmol}, 100 \%)$. ${ }^{1} \mathrm{H}$ NMR $\left(400 \mathrm{MHz}\right.$, DMSO- $\left.d_{6}\right) \delta 12.51(\mathrm{~s}, 1 \mathrm{H}), 9.15(\mathrm{~s}, 1 \mathrm{H}), 8.80(\mathrm{~d}, J=2.7 \mathrm{~Hz}, 1 \mathrm{H}), 8.55(\mathrm{dd}, J=9.0$, $\left.\left.2.8 \mathrm{~Hz}, 1 \mathrm{H}), 7.77(\mathrm{~d}, J=9.0 \mathrm{~Hz}, 1 \mathrm{H}), 4.74(\mathrm{~s}, 2 \mathrm{H}), 1.46(\mathrm{~s}, 9 \mathrm{H}) .{ }^{13} \mathrm{C}\right\}{ }^{1} \mathrm{H}\right\}$ NMR $\left(101 \mathrm{MHz}, \mathrm{DMSO}-d_{6}\right)$ $\delta 167.1,159.9,152.2,144.6,129.2,128.7,122.6,121.2,82.8,50.9,28.1$. HRMS (ESI/Q-TOF) $m / z:[\mathrm{M}]^{+}$ calculated for $\mathrm{C}_{18} \mathrm{H}_{17} \mathrm{~N}_{5} \mathrm{O}_{7}, 415.1128$; found, 415.1130 .

tert-Butyl 2-(5-(7-nitro-4-oxo-1,4-dihydroquinazolin-2-yl)uracil-1-yl)acetate (14)<smiles>CC(C)(C)OC(=O)CN1C=C(c2nc3cc([N+](=O)[O-])ccc3c(=O)[nH]2)NC(=O)N1</smiles>

To $1 \mathrm{~mL}$ of of DMSO was added $0.12 \mathrm{~g}(0.29 \mathrm{mmol})$ of 9 , and the temperature was increased to $60{ }^{\circ} \mathrm{C}$ until a clear solution was obtained. To the same solution were added $\mathrm{CuCl}(2.9 \mathrm{mg}, 0.02 \mathrm{mmol})$, 4-HO-TEMPO ( $2 \mathrm{mg}, 0.012 \mathrm{mmol})$ and DABCO $(2 \mathrm{mg}, 0.022 \mathrm{mmol})$, and the mixture was stirred at $90{ }^{\circ} \mathrm{C}$ overnight under $\mathrm{O}_{2}$ atmosphere (balloon). After the completion of the reaction (monitored by TLC), the reaction was cooled down to room temperature and the resulting precipitate was washed with water and ethanol to give the product 14 as a yellow solid $(0.12 \mathrm{~g}, 0.29 \mathrm{mmol}, 100 \%) .{ }^{1} \mathrm{H}$ NMR $\left(400 \mathrm{MHz}, \mathrm{DMSO}-d_{6}\right) \delta 12.50-12.39(\mathrm{~m}, 2 \mathrm{H}), 9.12(\mathrm{~s}, 1 \mathrm{H}), 8.36-8.27(\mathrm{~m}, 2 \mathrm{H}), 8.18(\mathrm{dd}, J=8.7,2.2 \mathrm{~Hz}$, $\left.\left.1 \mathrm{H}), 4.72(\mathrm{~s}, 2 \mathrm{H}), 1.46(\mathrm{~s}, 9 \mathrm{H}) .{ }^{13} \mathrm{C}\right\}{ }^{1} \mathrm{H}\right\} \mathrm{NMR}\left(101 \mathrm{MHz}, \mathrm{DMSO}-d_{6}\right) \delta 167.1,159.7,151.8,151.6,151.4$, 150.0, 149.6, 128.8, 125.7, 121.9, 119.8, 102.7, 82.8, 50.9, 28.1. HRMS (ESI/Q-TOF) $\mathrm{m} / z$ : [M] ${ }^{+}$calculated for $\mathrm{C}_{18} \mathrm{H}_{17} \mathrm{~N}_{5} \mathrm{O}_{7}, 415.1128$; found, 415.1133 .

tert-Butyl 2-(5-(7-methoxy-4-oxo-1,4-dihydroquinazolin-2-yl)uracil-1-yl)acetate (15)<smiles>COc1ccc2c(=O)[nH]c(-c3cn(CC(=O)OC(C)(C)C)c(=O)[nH]c3=O)nc2c1</smiles>

To $1 \mathrm{~mL}$ of of DMSO was added $0.14 \mathrm{~g}(0.35 \mathrm{mmol})$ of 10 , and the temperature was increased to $60^{\circ} \mathrm{C}$ until a clear solution was obtained. To the same solution were added $\mathrm{CuCl}(2.9 \mathrm{mg}, 0.02 \mathrm{mmol})$, 4-HO-TEMPO ( $2 \mathrm{mg}, 0.012 \mathrm{mmol})$ and DABCO ( $2 \mathrm{mg}, 0.022 \mathrm{mmol})$, and the mixture was stirred at $90{ }^{\circ} \mathrm{C}$ overnight under an $\mathrm{O}_{2}$ atmosphere (balloon). After the completion of the reaction (monitored by TLC), the reaction was cooled down to room temperature and the resulting precipitate was washed 
with water and ethanol to give the product 15 as a yellow solid $(0.14 \mathrm{~g}, 0.35 \mathrm{mmol}, 100 \%) .{ }^{1} \mathrm{H} \mathrm{NMR}$ $\left(400 \mathrm{MHz}, \mathrm{DMSO}-d_{6}\right) \delta 12.37(\mathrm{~s}, 1 \mathrm{H}), 12.03(\mathrm{~s}, 1 \mathrm{H}), 9.02(\mathrm{~s}, 1 \mathrm{H}), 8.02(\mathrm{~d}, J=8.7 \mathrm{~Hz}, 1 \mathrm{H}), 7.12-7.01(\mathrm{~m}$, 2H), $\left.\left.4.70(\mathrm{~s}, 2 \mathrm{H}), 3.89(\mathrm{~s}, 3 \mathrm{H}), 1.45(\mathrm{~s}, 9 \mathrm{H}) .{ }^{13} \mathrm{C}\right\}{ }^{1} \mathrm{H}\right\} \mathrm{NMR}\left(101 \mathrm{MHz}, \mathrm{DMSO}-d_{6}\right) \delta$ 167.2, 164.7, 164.5, 160.1, 151.3, 150.7, 150.1, 149.7, 128.1, 116.1, 114.8, 108.2, 103.2, 82.7, 56.1, 50.7, 28.1. HRMS (ESI/Q-TOF) $\mathrm{m} / \mathrm{z}:[\mathrm{M}]^{+}$calculated for $\mathrm{C}_{19} \mathrm{H}_{20} \mathrm{~N}_{4} \mathrm{O}_{6}, 400.1383$; found, 400.1379 .

tert-Butyl 2-(5-(6-methoxy-4-oxo-3,4-dihydroquinazolin-2-yl)uracil-1-yl)acetate (16)<smiles>COc1ccc2nc(-c3cn(CC(=O)OC(C)(C)C)c(=O)[nH]c3=O)[nH]c(=O)c2c1</smiles>

To $1 \mathrm{~mL}$ of of DMSO was added $0.14 \mathrm{~g}(0.35 \mathrm{mmol})$ of $\mathbf{1 1}$, and the temperature was increased to $60{ }^{\circ} \mathrm{C}$ until a clear solution was obtained. To the same solution were added $\mathrm{CuCl}(2.9 \mathrm{mg}, 0.02 \mathrm{mmol})$, 4-HO-TEMPO ( $2 \mathrm{mg}, 0.012 \mathrm{mmol})$ and DABCO ( $2 \mathrm{mg}, 0.022 \mathrm{mmol})$, and the mixture was stirred at $90{ }^{\circ} \mathrm{C}$ overnight under an $\mathrm{O}_{2}$ atmosphere (balloon). After the completion of the reaction (monitored by TLC), the reaction was cooled down to room temperature and the resulting precipitate was washed with water and ethanol to give the product 16 as a yellow solid $(0.14 \mathrm{~g}, 0.35 \mathrm{mmol}, 100 \%) .{ }^{1} \mathrm{H}$ NMR $\left(400 \mathrm{MHz}, \mathrm{DMSO}-d_{6}\right) \delta 12.37(\mathrm{~s}, 1 \mathrm{H}), 12.03(\mathrm{~s}, 1 \mathrm{H}), 9.02(\mathrm{~s}, 1 \mathrm{H}), 8.02(\mathrm{~d}, J=8.7 \mathrm{~Hz}, 1 \mathrm{H}), 7.12-7.01(\mathrm{~m}$, 2H), $\left.\left.4.70(\mathrm{~s}, 2 \mathrm{H}), 3.89(\mathrm{~s}, 3 \mathrm{H}), 1.45(\mathrm{~s}, 9 \mathrm{H}) .{ }^{13} \mathrm{C}\right\}{ }^{1} \mathrm{H}\right\}$ NMR $\left(101 \mathrm{MHz}\right.$, DMSO- $\left.d_{6}\right) \delta 167.2,164.7,164.5$, 160.1, 151.3, 150.7, 150.1, 149.7, 128.1, 116.1, 114.8, 108.2, 103.2, 82.7, 56.1, 50.7, 28.1. HRMS (ESI/Q-TOF) $m / z:[\mathrm{M}]^{+}$calculated for $\mathrm{C}_{19} \mathrm{H}_{20} \mathrm{~N}_{4} \mathrm{O}_{6}, 400.1383$; found, 400.1382 .

tert-Butyl (2-aminoethyl)glycinate (17)<smiles>CC(C)(C)OC(=O)CNCCN</smiles>

tert-Butyl bromoacetate $(6.9 \mathrm{~mL}, 47 \mathrm{mmol})$ was mixed with $37.5 \mathrm{~mL}$ of dichloromethane and added dropwise to a mixture of $25 \mathrm{~mL}$ ( $0.37 \mathrm{~mol}$ ) of ethylenediamine (dissolved in $175 \mathrm{~mL}$ of dichloromethane) in an ice bath. The reaction continued for $19 \mathrm{~h}$. Then, it was extracted with water $(90 \mathrm{~mL} \times 2)$ and dichloromethane $(60 \mathrm{~mL} \times 3)$, dried with sodium sulphate and concentrated in vacuo to give $15.8 \mathrm{~g}$ (90 mmol, $51 \%$ ) of ester 17 as a colorless liquid. ${ }^{1} \mathrm{H}$ NMR $(400 \mathrm{MHz}$, Chloroform-d) $\delta 3.22(\mathrm{~s}, 2 \mathrm{H})$, 2.74-2.66 (m, 2H), 2.64-2.52 (m, 2H), $1.39(\mathrm{~s}, 9 \mathrm{H})$.

\section{tert-Butyl (2-(((9H-fluoren-9-yl)methoxy)carbonyl)amino)ethyl)glycinate (18)}<smiles>CC(C)(C)OC(=O)C(Cl)NCCNCCF</smiles>

Ester $17(15.0 \mathrm{~g}, 88 \mathrm{mmol})$ and $15.2 \mathrm{~mL}$ of diisopropylethylamine $(90 \mathrm{mmol})$ were dissolved in $680 \mathrm{~mL}$ of dichloromethane. To this solution was added, dropwise over the course of $70 \mathrm{~min}$, a solution of $26.3 \mathrm{~g}$ (77 mmol) of Fmoc-OSu dissolved in $192 \mathrm{~mL}$ of dichloromethane. The reaction mixture was stirred overnight and washed with $1 \mathrm{M} \mathrm{HCl}(3 \times 100 \mathrm{~mL})$ and brine $(100 \mathrm{~mL})$. The organic layer was dried with sodium sulphate and filtered. The solution was partially concentrated to $50 \mathrm{~mL}$ in vacuo and cooled in a freezer $\left(-20^{\circ} \mathrm{C}\right)$ overnight. The white precipitate was filtered the next day and washed with dichloromethane and mother liquor and then returned to the freezer to generate more of product $18(8.0 \mathrm{~g}, 19 \mathrm{mmol}, 20 \%)$ as a white precipitate. ${ }^{1} \mathrm{H}$ NMR $\left(400 \mathrm{MHz}, \mathrm{DMSO}-d_{6}\right) \delta 7.91-7.80(\mathrm{~m}, 3 \mathrm{H}), 7.68$ $(\mathrm{dd}, J=16.3,7.9 \mathrm{~Hz}, 2 \mathrm{H}), 7.46-7.23(\mathrm{~m}, 5 \mathrm{H}), 4.36-4.27(\mathrm{~m}, 2 \mathrm{H}), 4.22(\mathrm{q}, J=7.3 \mathrm{~Hz}, 1 \mathrm{H}), 3.20(\mathrm{~s}, 1 \mathrm{H}), 3.07$ $\left.\left.(\mathrm{q}, J=6.2 \mathrm{~Hz}, 2 \mathrm{H}), 2.58(\mathrm{t}, J=6.4 \mathrm{~Hz}, 1 \mathrm{H}), 1.41(\mathrm{~s}, 9 \mathrm{H}) .{ }^{13} \mathrm{C}\right\}{ }^{1} \mathrm{H}\right\} \mathrm{NMR}\left(101 \mathrm{MHz}\right.$, DMSO- $\left.d_{6}\right) \delta 171.9$, 
156.7, 144.4, 141.2, 129.4, 128.0, 127.7, 127.5, 125.6, 121.8, 120.6, 120.5, 110.1, 80.5, 65.8, 51.3, 48.7, 47.2, $40.8,28.2$. This corresponded to the NMR spectra previously reported in the literature [22].

2-(2,4-dioxo-5-(4-oxo-3,4-dihydroquinazolin-2-yl)uracil-1-yl)acetic acid (19)<smiles>O=C(O)CN1C=C(c2nc3ccccc3c(=O)[nH]2)NC(=O)N1</smiles>

To $0.1 \mathrm{~g}(0.27 \mathrm{mmol})$ of ester 12 were added TFA $(1 \mathrm{~mL})$ and triethylsilane (three drops). The reaction was stirred for $2 \mathrm{~h}$ at room temperature, then the excess acid was evaporated under a nitrogen stream, and the product was washed with hexanes and ethyl ether to give acid 19 as a yellow solid (67 mg, $0.21 \mathrm{mmol}, 80 \%) .{ }^{1} \mathrm{H}$ NMR $\left(400 \mathrm{MHz}, \mathrm{DMSO}-d_{6}\right) 12.66(\mathrm{~s}, 1 \mathrm{H}), 9.27(\mathrm{~s}, 1 \mathrm{H}), 8.38(\mathrm{~d}, J=7.9 \mathrm{~Hz}, 1 \mathrm{H})$, $\left.\left.8.08(\mathrm{t}, J=7.7 \mathrm{~Hz}, 1 \mathrm{H}), 7.92(\mathrm{~d}, J=8.2 \mathrm{~Hz}, 1 \mathrm{H}), 7.64(\mathrm{t}, J=7.5 \mathrm{~Hz}, 1 \mathrm{H}), 4.86(\mathrm{~s}, 2 \mathrm{H}) .{ }^{13} \mathrm{C}\right\}{ }^{1} \mathrm{H}\right\} \mathrm{NMR}(101$ MHz, DMSO-d 6 ) $\delta 169.4,166.8,164.3,150.5,150.0,149.1,134.8,126.4,126.3,121.5,110.0,103.5,82.8$, 50.8. HRMS (ESI/Q-TOF) $m / z$ : $[\mathrm{M}]^{+}$calculated for $\mathrm{C}_{14} \mathrm{H}_{10} \mathrm{~N}_{4} \mathrm{O}_{5}, 314.0651$; found, 314.0658 .

2-(5-(6-nitro-4-oxo-3,4-dihydroquinazolin-2-yl)uracil-1-yl)acetic acid (20)<smiles>O=C(O)Cn1cc(-c2nc3ccc([N+](=O)[O-])cc3c(=O)[nH]2)c(=O)[nH]c1=O</smiles>

To $0.1 \mathrm{~g}(0.24 \mathrm{mmol})$ of ester 13 were added TFA $(1 \mathrm{~mL})$ and triethylsilane (three drops). The reaction was stirred for $2 \mathrm{~h}$ at room temperature, then the excess acid was evaporated under a nitrogen stream, and the product was washed with hexane and ethyl ether to give acid 20 as a yellow solid (70 mg, $0.19 \mathrm{mmol}, 80 \%) .{ }^{1} \mathrm{H}$ NMR $\left(400 \mathrm{MHz}\right.$, DMSO- $\left.d_{6}\right) \delta 13.39(\mathrm{~s}, 1 \mathrm{H}), 12.49(\mathrm{~s}, 1 \mathrm{H}), 9.16(\mathrm{~d}, J=1.4 \mathrm{~Hz}, 1 \mathrm{H})$, $\left.\left.8.78(\mathrm{q}, J=2.6 \mathrm{~Hz}, 1 \mathrm{H}), 8.54(\mathrm{dq}, J=9.1,2.6 \mathrm{~Hz}, 1 \mathrm{H}), 7.80-7.72(\mathrm{~m}, 2 \mathrm{H}), 4.76(\mathrm{~s}, 2 \mathrm{H}) .{ }^{13} \mathrm{C}\right\}{ }^{1} \mathrm{H}\right\} \mathrm{NMR}(101$ MHz, DMSO- $\left.d_{6}\right) \delta 169.4,164.5,160.0,152.6,152.3,149.9,144.5,129.2,128.7,122.6,121.2,102.4,56.5$, 50.3, 19.0. HRMS (ESI/Q-TOF) $m / z$ : [M] ${ }^{+}$calculated for $\mathrm{C}_{14} \mathrm{H}_{9} \mathrm{~N}_{5} \mathrm{O}_{7}, 359.0502$; found, 359.0509 .

2-(5-(6-methoxy-4-oxo-3,4-dihydroquinazolin-2-yl)uracil-1-yl)acetic acid (21)<smiles>COc1ccc2nc(-c3cn(CC(=O)O)c(=O)[nH]c3=O)[nH]c(=O)c2c1</smiles>

To $0.1 \mathrm{~g}(0.25 \mathrm{mmol})$ of ester 16 were added TFA $(1 \mathrm{~mL})$ and triethylsilane (three drops). The reaction was stirred for $2 \mathrm{~h}$ at room temperature, then the excess acid was evaporated under a nitrogen stream, and the product was washed with hexane and ethyl ether to give acid 21 as a light green solid (65 mg, $0.19 \mathrm{mmol}, 75 \%) .{ }^{1} \mathrm{H}$ NMR $\left(400 \mathrm{MHz}, \mathrm{DMSO}-\mathrm{d}_{6}\right) \delta 12.32(\mathrm{~s}, 1 \mathrm{H}), 12.13(\mathrm{~s}, 1 \mathrm{H}), 8.95(\mathrm{~s}, 1 \mathrm{H}), 7.59(\mathrm{~d}, J=$ $\left.\left.8.9 \mathrm{~Hz}, 1 \mathrm{H}), 7.51(\mathrm{~d}, J=3.0 \mathrm{~Hz}, 1 \mathrm{H}), 7.43(\mathrm{dd}, J=8.9,3.0 \mathrm{~Hz}, 1 \mathrm{H}), 4.72(\mathrm{~s}, 2 \mathrm{H}), 3.88(\mathrm{~s}, 3 \mathrm{H}) .{ }^{13} \mathrm{C}\right\}^{1} \mathrm{H}\right\} \mathrm{NMR}$ $\left(101 \mathrm{MHz}, \mathrm{DMSO}-d_{6}\right) \delta 169.6,164.5,160.4,157.8,150.2,150.1,146.9,143.6,128.9,124.8,122.1,106.4$, 103.5, 56.1, 50.0. HRMS (ESI/Q-TOF) $m / z$ : $[\mathrm{M}]^{+}$calculated for $\mathrm{C}_{15} \mathrm{H}_{12} \mathrm{~N}_{4} \mathrm{O}_{6}, 344.0757$; found, 344.0759 .

tert-Butyl N-(2-(((9H-fluoren-9-yl)methoxy)carbonyl)amino)ethyl)-N-(2-(2,4-dioxo-5-(4-oxo-3,4dihydroquinazolin-2-yl)uracil-1-yl)acetyl)glycinate (22) 


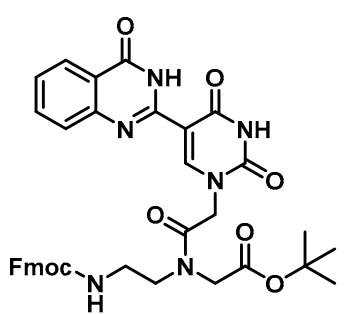

In $2 \mathrm{~mL}$ of $\mathrm{DMF}$ at $0{ }^{\circ} \mathrm{C}$ were dissolved $60 \mathrm{mg}(0.19 \mathrm{mmol})$ of $19, \mathrm{HOBt}(24 \mathrm{mg}, 0.18 \mathrm{mmol})$ and DCC (67 mg, $0.32 \mathrm{mmol})$. This mixture was stirred until the formation of precipitation was observed, then $70 \mathrm{mg}(0.15 \mathrm{mmol})$ of 6 as a free base with DMAP $(1.8 \mathrm{mg}, 0.015 \mathrm{mmol})$ were added, and the reaction continued for $3 \mathrm{~h}$ and was checked by TLC. The mixture was diluted with saturated aqueous $\mathrm{NaHCO}_{3}$, extracted with dichloromethane (DCM), washed with brine, concentrated in vacuo and purified by column chromatography (1:1 to 4:1 ethyl acetate/hexanes) to yield 22 as a white solid (81 mg, $0.1 \mathrm{mmol}, 62 \%) .{ }^{1} \mathrm{H}$ NMR (400 MHz, DMF- $\left.d_{7}\right) \delta 8.38$ (dd, $\left.J=7.7,3.6 \mathrm{~Hz}, 3 \mathrm{H}\right), 8.09$ (dd, $J=10.0$, $7.5 \mathrm{~Hz}, 3 \mathrm{H}), 7.84(\mathrm{dd}, J=8.6,6.2 \mathrm{~Hz}, 3 \mathrm{H}), 7.79-7.71(\mathrm{~m}, 3 \mathrm{H}), 4.85-4.57(\mathrm{~m}, 4 \mathrm{H}), 4.43(\mathrm{~d}, J=4.0 \mathrm{~Hz}, 2 \mathrm{H})$, $4.02(\mathrm{~d}, J=2.4 \mathrm{~Hz}, 1 \mathrm{H}), 3.38-3.27(\mathrm{~m}, 3 \mathrm{H}), 2.76(\mathrm{q}, J=7.3 \mathrm{~Hz}, 1 \mathrm{H}), 1.84(\mathrm{~s}, 9 \mathrm{H}) .{ }^{13} \mathrm{C}\left\{{ }^{1} \mathrm{H}\right\} \mathrm{NMR}(101 \mathrm{MHz}$, DMF- $\left.d_{7}\right) \delta 169.99,153.96,144.68,141.65,129.81,128.57,128.17,128.01,128.00,125.97,122.27,121.03$, $110.63,81.40,68.20,67.64,67.23,55.58,55.30,48.40,47.59,33.9,31.2,28.1$. HRMS (ESI/Q-TOF) $m / z:[M+$ $\mathrm{Na}]^{+}$calculated for $\mathrm{C}_{37} \mathrm{H}_{36} \mathrm{~N}_{6} \mathrm{O}_{8} \mathrm{Na}, 715.2492$; found, 715.2487.

tert-Butyl N-(2-(((9H-fluoren-9-yl)methoxy)carbonyl)amino)ethyl)-N-(2-(5-(6-methoxy-4-oxo-3,4dihydroquinazolin-2-yl)uracil-1-yl)acetyl)glycinate (23)<smiles>COc1ccc2nc(-c3cn(CC(=O)N(CCNCC(F)F)CC(=O)OC(C)(C)C)c(=O)[nH]c3=O)c(=O)[nH]c2c1</smiles>

To $0.1 \mathrm{~g}$ ( $0.29 \mathrm{mmol})$ of 21 dissolved in $2 \mathrm{~mL}$ of DMF at $0{ }^{\circ} \mathrm{C}$ were added HOBt $(26 \mathrm{mg}, 0.20 \mathrm{mmol})$ and DCC (70 mg, $0.34 \mathrm{mmol})$. This reaction was stirred until the formation of precipitation was observed, then $70 \mathrm{mg}(0.15 \mathrm{mmol})$ of 6 as a free base with DMAP $(1.8 \mathrm{mg}, 0.015 \mathrm{mmol})$ were added, and the reaction continued for $3 \mathrm{~h}$ and was checked by TLC. The mixture was diluted with saturated aqueous $\mathrm{NaHCO}_{3}$, extracted with DCM, washed with brine, concentrated in vacuo and purified by column chromatography (1:1 to 4:1 ethyl acetate/hexanes) to yield 23 as a white solid (77 $\mathrm{mg}, 0.1 \mathrm{mmol}$, $66 \%) .{ }^{1} \mathrm{H}$ NMR (400 MHz, DMF- $\left.d_{7}\right) \delta 8.31(\mathrm{dd}, J=7.7,3.6 \mathrm{~Hz}, 3 \mathrm{H}), 8.07(\mathrm{dd}, J=10.0,7.5 \mathrm{~Hz}, 3 \mathrm{H})$, $7.84(\mathrm{dd}, J=8.6,6.2 \mathrm{~Hz}, 3 \mathrm{H}), 7.79-7.71(\mathrm{~m}, 3 \mathrm{H}), 4.83-4.59(\mathrm{~m}, 4 \mathrm{H}), 4.43(\mathrm{~d}, J=4.0 \mathrm{~Hz}, 2 \mathrm{H}), 4.01(\mathrm{~d}, J=$ $2.4 \mathrm{~Hz}, 1 \mathrm{H}), 3.75(\mathrm{~s}, 3 \mathrm{H}), 3.36-3.26(\mathrm{~m}, 3 \mathrm{H}), 2.76(\mathrm{q}, J=7.3 \mathrm{~Hz}, 1 \mathrm{H}), 1.84(\mathrm{~s}, 9 \mathrm{H}) .{ }^{13} \mathrm{C}\left\{{ }^{1} \mathrm{H}\right\} \mathrm{NMR}(101 \mathrm{MHz}$, DMF- $\left.d_{7}\right) \delta 169.99,153.96,144.68,141.65,129.81,128.57,128.17,128.01,128.00,125.97,122.27,121.03$, $110.63,81.40,68.20,67.64,67.23,55.58,55.30,52.05,48.40,47.59,32.9,30.2,28.1$. HRMS (ESI/Q-TOF) $m / z$ : $[\mathrm{M}+\mathrm{Na}]^{+}$calculated for $\mathrm{C}_{38} \mathrm{H}_{38} \mathrm{~N}_{6} \mathrm{O}_{9} \mathrm{Na}, 745.2598$; found, 745.2590.

tert-Butyl N-(2-(((9H-fluoren-9-yl)methoxy)carbonyl)amino)ethyl)- $N$-(2-(5-(6-nitro-4-oxo-3,4dihydroquinazolin-2-yl)uracil-1-yl)acetyl)glycinate (24) 
<smiles>CC(C)(C)OC(=O)CN(CCNC(F)F)C(=O)Cn1cc(-c2nc3ccc([N+](=O)[O-])cc3c(=O)[nH]2)c(=O)[nH]c1=O</smiles>

To $0.1 \mathrm{~g}(0.24 \mathrm{mmol})$ of 20 dissolved in $2 \mathrm{~mL}$ of DMF at $0{ }^{\circ} \mathrm{C}$ were added HOBt $(23 \mathrm{mg}, 0.19$ $\mathrm{mmol})$ and DCC (70 $\mathrm{mg}, 0.34 \mathrm{mmol})$, and the reaction was stirred until the formation of precipitation was observed. Then, $70 \mathrm{mg}(0.15 \mathrm{mmol})$ of 6 as a free base with DMAP $(1.8 \mathrm{mg}, 0.015 \mathrm{mmol})$ were added, and the reaction continued for $3 \mathrm{~h}$ and was checked by TLC. The mixture was diluted with saturated aqueous $\mathrm{NaHCO}_{3}$, extracted with $\mathrm{DCM}$, washed with brine, concentrated in vacuo and purified by column chromatography (1:1 to 4:1 ethyl acetate/hexanes) to yield 24 as a yellow solid (66 mg, $0.09 \mathrm{mmol}, 60 \%) .{ }^{1} \mathrm{H}$ NMR (400 MHz, DMSO-d 6 ) $\delta 8.85-8.70(\mathrm{~m}, 1 \mathrm{H}), 7.91-7.82(\mathrm{~m}, 3 \mathrm{H}), 7.69$ $(\mathrm{dd}, J=10.0,7.0 \mathrm{~Hz}, 2 \mathrm{H}), 7.47-7.18(\mathrm{~m}, 5 \mathrm{H}), 4.01(\mathrm{ddd}, J=15.7,14.1,5.9 \mathrm{~Hz}, 1 \mathrm{H}), 3.19(\mathrm{~d}, J=3.2 \mathrm{~Hz}, 4 \mathrm{H})$, $2.90(\mathrm{~s}, 1 \mathrm{H}), 2.75-2.56(\mathrm{~m}, 7 \mathrm{H}), 1.42(\mathrm{~s}, 9 \mathrm{H}) .{ }^{13} \mathrm{C}\left\{{ }^{1} \mathrm{H}\right\} \mathrm{NMR}(101 \mathrm{MHz}$, Chloroform-d $) \delta 171.9,146.0,141.0$, $128.7,127.4,127.2,127.1,126.9,126.9,125.2,124.7,121.0,119.9,119.8,119.7,107.7,81.3,57.3,53.0,51.4$, $48.8,47.9,44.7,33.9,31.2,28.1$. HRMS (ESI/Q-TOF) $m / z:[\mathrm{M}+\mathrm{Na}]^{+}$calculated for $\mathrm{C}_{37} \mathrm{H}_{35} \mathrm{~N}_{7} \mathrm{O}_{10} \mathrm{Na}_{\text {, }}$ 760.2343; found, 760.2350 .

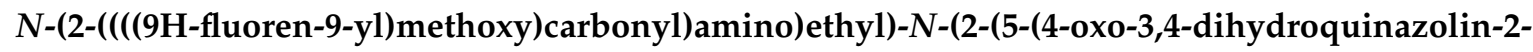
yl)uracil-1-yl)acetyl)glycine (25)<smiles>O=C(O)CN(CCNC(F)F)C(=O)Cn1cc(-c2nc3ccccc3c(=O)[nH]2)c(=O)[nH]c1=O</smiles>

To $75 \mathrm{mg}(0.10 \mathrm{mmol})$ of ester 22 were added TFA $(1 \mathrm{~mL})$ and triethylsilane (three drops). The reaction was stirred for $2 \mathrm{~h}$ at room temperature, then the excess acid was evaporated under a nitrogen stream, and the product was washed with hexane and ethyl ether to give acid 25 as a white solid (55 mg, $0.08 \mathrm{mmol}, 80 \%) .{ }^{1} \mathrm{H} \mathrm{NMR}\left(400 \mathrm{MHz}, \mathrm{DMSO}-d_{6}\right) \delta 12.34(\mathrm{~s}, 3 \mathrm{H}), 8.76(\mathrm{~s}, 2 \mathrm{H}), 8.71(\mathrm{~s}, 1 \mathrm{H})$, $7.81(\mathrm{dd}, J=7.5,5.1 \mathrm{~Hz}, 6 \mathrm{H}), 7.68(\mathrm{t}, J=6.8 \mathrm{~Hz}, 6 \mathrm{H}), 7.49(\mathrm{ddd}, J=8.4,5.2,1.6 \mathrm{~Hz}, 8 \mathrm{H}), 7.38(\mathrm{dt}, J=7.9$, $2.1 \mathrm{~Hz}, 6 \mathrm{H}), 7.35-7.29(\mathrm{~m}, 6 \mathrm{H}), 5.57(\mathrm{~s}, 1 \mathrm{H}), 5.03(\mathrm{~s}, 3 \mathrm{H}), 4.84(\mathrm{~s}, 2 \mathrm{H}), 4.36(\mathrm{~d}, J=6.9 \mathrm{~Hz}, 4 \mathrm{H}), 4.23(\mathrm{~d}, J=$ $7.0 \mathrm{~Hz}, 2 \mathrm{H}), 4.25(\mathrm{t}, J=3.4 \mathrm{~Hz}, 4 \mathrm{H}), 4.02(\mathrm{~s}, 3 \mathrm{H}), 1.25-1.03(\mathrm{~m}, 9 \mathrm{H}) .{ }^{13} \mathrm{C}\left\{{ }^{1} \mathrm{H}\right\}$ NMR $(101 \mathrm{MHz}, \mathrm{DMSO}) \delta$ $171.9,170.5,165.2,164.6,160.6,157.7,156.8,156.6,150.4,150.1,144.3,141.2,141.1,134.3,128.1,128.0$, 127.8, 127.5, 125.6, 125.6, 120.6, 106.4, 103.1, 49.4, 47.9, 47.2, 40.6, 40.4, 40.2, 39.9, 39.78, 39.6, 39.4, 36.7, 33.8, 25.8, 24.9. HRMS (ESI/Q-TOF) $m / z$ : $[\mathrm{M}+\mathrm{Na}]^{+}$calculated for $\mathrm{C}_{33} \mathrm{H}_{28} \mathrm{~N}_{6} \mathrm{O}_{8} \mathrm{Na}, 659.1866$; found, 659.1859.

$N-(2-(((9 H-f l u o r e n-9-y l) m e t h o x y)$ carbonyl)amino)ethyl)-N-(2-(5-(6-methoxy-4-oxo-3,4dihydroquinazolin-2-yl)uracil-1-yl)acetyl)glycine (26)<smiles></smiles> 
To $66 \mathrm{mg}(0.09 \mathrm{mmol})$ of ester 23 were added TFA $(1 \mathrm{~mL})$ and triethylsilane (three drops). The reaction was stirred for $2 \mathrm{~h}$ at room temperature, then the excess acid was evaporated under a nitrogen stream, and the product was washed with hexane and ethyl ether to give acid $\mathbf{2 6}$ as a white solid (47 mg, $0.07 \mathrm{mmol}, 75 \%) .{ }^{1} \mathrm{H}$ NMR (400 MHz, DMSO- $\left.d_{6}\right) \delta 12.30(\mathrm{~s}, 3 \mathrm{H}), 8.78(\mathrm{~s}, 2 \mathrm{H}), 8.72(\mathrm{~s}, 1 \mathrm{H})$, $7.86(\mathrm{dd}, J=7.5,5.1 \mathrm{~Hz}, 6 \mathrm{H}), 7.68(\mathrm{t}, J=6.8 \mathrm{~Hz}, 6 \mathrm{H}), 7.49(\mathrm{ddd}, J=8.4,5.2,1.6 \mathrm{~Hz}, 8 \mathrm{H}), 7.38(\mathrm{dt}, J=7.9$, $2.1 \mathrm{~Hz}, 6 \mathrm{H}), 7.35-7.29(\mathrm{~m}, 6 \mathrm{H}), 5.57(\mathrm{~s}, 1 \mathrm{H}), 5.03(\mathrm{~s}, 3 \mathrm{H}), 4.84(\mathrm{~s}, 2 \mathrm{H}), 4.36(\mathrm{~d}, J=6.9 \mathrm{~Hz}, 4 \mathrm{H}), 4.29(\mathrm{~d}, J=$ $7.0 \mathrm{~Hz}, 2 \mathrm{H}), 4.25(\mathrm{t}, J=3.4 \mathrm{~Hz}, 4 \mathrm{H}), 4.02(\mathrm{~s}, 3 \mathrm{H}), 3.88(\mathrm{~s}, 3 \mathrm{H}), 1.27-1.03(\mathrm{~m}, 9 \mathrm{H}) .{ }^{13} \mathrm{C}\left\{{ }^{1} \mathrm{H}\right\} \mathrm{NMR}(101 \mathrm{MHz}$, DMSO) $\delta 172.8,170.8,167.2,164.6,160.6,157.7,156.8,156.6,150.4,150.1,144.3,141.2,141.1,134.3,128.1$, 128.0, 127.8, 127.5, 125.6, 125.6, 120.6, 106.4, 103.1, 56.1, 49.4, 47.9, 47.2, 40.6, 40.4, 40.2, 39.9, 39.78, 39.6, 39.4, 36.7, 33.8, 25.8, 24.9. HRMS (ESI/Q-TOF) $m / z$ : $[\mathrm{M}+\mathrm{Na}]^{+}$calculated for $\mathrm{C}_{34} \mathrm{H}_{36} \mathrm{~N}_{6} \mathrm{O}_{9} \mathrm{Na}, 695.2441$; found, 695.2458 .

\section{$N-(2-(((9 H-f l u o r e n-9-y l) m e t h o x y)$ carbonyl)amino)ethyl)- $N$-(2-(5-(6-nitro-4-oxo-3,4- dihydroquinazolin-2-yl)uracil-1-yl)acetyl)glycine (27)}<smiles>O=CNCCN(CC(=O)O)C(=O)CN1C=C(c2nc3ccc([N+](=O)[O-])cc3c(=O)[nH]2)NC(=O)N1</smiles>

To ester 24 ( $58 \mathrm{mg}, 0.07 \mathrm{mmol})$ were added TFA $(1 \mathrm{~mL})$ and triethylsilane (three drops). The reaction was stirred for $2 \mathrm{~h}$ at room temperature, then the excess acid was evaporated under a nitrogen stream, and the product was washed with hexane and ethyl ether to give acid 27 as a light yellow solid $(47 \mathrm{mg}$, $0.05 \mathrm{mmol}, 83 \%) .{ }^{1} \mathrm{H}$ NMR $\left(400 \mathrm{MHz}, \mathrm{DMSO}-d_{6}\right) \delta 12.57(\mathrm{~s}, 1 \mathrm{H}), 9.05(\mathrm{~d}, J=3.4 \mathrm{~Hz}, 2 \mathrm{H}), 8.81(\mathrm{~s}, 3 \mathrm{H})$, $8.55(\mathrm{~d}, J=8.9 \mathrm{~Hz}, 4 \mathrm{H}), 8.49(\mathrm{~s}, 2 \mathrm{H}), 7.91(\mathrm{~d}, J=7.2 \mathrm{~Hz}, 3 \mathrm{H}), 7.86(\mathrm{t}, J=9.8 \mathrm{~Hz}, 5 \mathrm{H}), 7.76(\mathrm{dd}, J=14.8$, $8.1 \mathrm{~Hz}, 6 \mathrm{H}), 7.69(\mathrm{~s}, 3 \mathrm{H}), 7.46-7.29(\mathrm{~m}, 11 \mathrm{H}), 5.07(\mathrm{~s}, 2 \mathrm{H}), 4.87(\mathrm{~s}, 2 \mathrm{H}), 4.68(\mathrm{~s}, 3 \mathrm{H}), 4.13(\mathrm{~s}, 2 \mathrm{H}), 4.03(\mathrm{~s}$, $2 \mathrm{H}), 3.56(\mathrm{~s}, 4 \mathrm{H}), 3.28(\mathrm{~s}, 8 \mathrm{H}), 2.92(\mathrm{~d}, J=21.0 \mathrm{~Hz}, 11 \mathrm{H}) .{ }^{13} \mathrm{C}\left\{{ }^{1} \mathrm{H}\right\} \mathrm{NMR}\left(101 \mathrm{MHz}, \mathrm{DMSO}-d_{6}\right) \delta 171.7$, 169.7, 167.1, 163.5, 160.6, 157.8, 156.8, 156.6, 150.4, 150.1, 144.3, 141.2, 141.1, 134.3, 128.1, 128.0, 127.8, 127.5, 125.6, 125.6, 120.5, 106.4, 103.1, 49.4, 47.9, 47.2, 40.6, 40.4, 40.2, 39.9, 39.8, 39.6, 39.4, 36.7, 33.8, 25.8, 24.9. HRMS (ESI/Q-TOF) $m / z$ : [M+Na] $]^{+}$calculated for $\mathrm{C}_{33} \mathrm{H}_{27} \mathrm{~N}_{7} \mathrm{O}_{10} \mathrm{Na}, 704.1717$; found, 704.1739.

\subsection{Oligomer Synthesis}

PNA oligomers were synthesized using the ABI 433A peptide synthesizer, using manufacturersupplied "Fastmoc" cycles. Oligomerization was carried out using newly synthesized quinazolinone heterocycle monomers and commercially available Fmoc-A(Bhoc)-AEG-OH, Fmoc-G(Bhoc)-AEG-OH, Fmoc-C(Bhoc)-AEG-OH and Fmoc-T(Bhoc)-AEG-OH (purchased from PolyOrg, Inc.), and $N \alpha$-Fmoc-NE-Boc-L-lysine (Chem-Impex International Inc.). FmocRAM-PS was used as a solid support resin, preloaded with L-lysine at $0.057 \mathrm{mmol} / \mathrm{g}$. The synthesis was carried out on a $5.0 \mu \mathrm{mol}$ scale. The synthesis cycle was only modified by using $20 \% 4$-methylpiperidine in dimethylformamide for Fmoc deprotection [23]. Following automated synthesis, the resin was treated with a solution of $95 \%$ trifluoroacetic acid and 5\% triethylsilane to cleave the oligomer from the resin and remove the protecting group from the nucleobases (Bhoc) and amino group (Boc). The solvent was then evaporated under a nitrogen stream and the resulting residue was washed twice with cold ether, dissolved in a solution of $0.05 \%$ trifluoroacetic acid in water and then purified by reverse-phase HPLC. Reverse-phase HPLC was performed on an Agilent MicrosorbMV 100-5 C18 $250 \times 4.6 \mathrm{~mm}$ column heated to $50{ }^{\circ} \mathrm{C}$. The purified PNA oligomer was eluted using a gradient (water $/ 0.1 \%$ trifluoroacetic acid to acetonitrile/ $0.1 \%$ trifluoroacetic acid) over $60 \mathrm{~min}$. 


\subsection{Thermal Stability Analysis}

The thermal stabilities (melting temperature, $\mathrm{T}_{\mathrm{m}}$ ) of complexes were measured in solutions of $100 \mathrm{mM} \mathrm{NaCl}, 10 \mathrm{mM}$ sodium hydrogen phosphate, $0.1 \mathrm{mM}$ EDTA, $\mathrm{pH}=7.0$ with individual PNA strand concentrations of $2 \mu \mathrm{M}$. Absorbance at $\lambda=260 \mathrm{~nm}$ was measured at $0.5^{\circ} \mathrm{C}$ intervals while the temperature was changed at a rate of $0.7^{\circ} \mathrm{C} / \mathrm{min}$ between 15 and $90^{\circ} \mathrm{C} . \mathrm{T}_{\mathrm{m}}$ values were measured in triplicate and determined by the first derivative method applied through the manufacturer-supplied Varian WinUV Bio software.

\subsection{Computational Studies}

Structures were constructed in Spartan '14 and ground state energy was minimized using a desktop computer at the Hartree-Foch $6-31+G^{*}$ level. A tautomer search was conducted at the Hartree-Foch $6-31+G^{*}$ level in order to confirm the lowest energy structures that represented the most favorable tautomeric forms.

\section{Conclusions}

A facile synthesis of C5-(quinazolinone)-uracil PNA monomers has been established that is compatible with standard Fmoc-based oligomerization chemistry. The modified nucleobases bearing quinazolinone moieties were characterized by their fluorescence quantum yield in nonpolar (THF) and polar solvents (EtOH, DMSO), and their responses to changes in viscosity and temperature are consistent with molecular rotor behavior. Single modifications incorporated into a PNA decamer resulted in the stabilization of hybrids formed with complementary DNA, as judged by the UV-vis

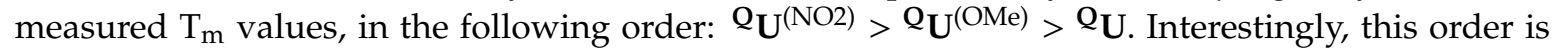
qualitatively reflected by the degree of fluorescence increase going from the single-stranded PNA to the PNA-DNA heteroduplex $\left({ }^{\mathrm{Q}} \mathbf{U}^{(\mathrm{NO} 2)}>{ }^{\mathrm{Q}} \mathbf{U}^{(\mathrm{OMe})}>{ }^{\mathrm{Q}} \mathbf{U}\right)$. The ${ }^{\mathrm{Q}} \mathbf{U}^{(\mathrm{OMe})}$ and ${ }^{\mathrm{Q}} \mathbf{U}$ labelled PNA oligomers dually report hybridization by an increase in fluorescence intensity and a large $(\sim 50 \mathrm{~nm})$ hypsochromic shift. Thus, quinazolinone-based uracil analogs are good candidates for reporting binding events by showing emission "turn-on" properties upon hybridization to complementary DNA.

Supplementary Materials: Supplementary figures and tables, additional characterization information and NMR spectra.

Author Contributions: Conceptualization, A.G.-C. and R.H.E.H.; methodology and execution, A.H., M.H., A.G.-C. and R.H.E.H.; analysis, A.H. and R.H.E.H.; writing-original draft preparation, A.H. and R.H.E.H.; writing-review and editing, A.H. and R.H.E.H; supervision, R.H.E.H.; funding acquisition, R.H.E.H. All authors have read and agreed to the published version of the manuscript.

Funding: Natural Sciences and Engineering Research Council of Canada.

Acknowledgments: We gratefully acknowledge sabbatical support from Ilam University (A.G.-C. and M.H.).

Conflicts of Interest: The authors declare no conflict of interest.

\section{References}

1. Daniels, M.; Hauswirth, W. Fluorescence of the Purine and Pyrimidine Bases of the Nucleic Acids in Neutral Aqueous Solution at 300 K. Science 1971, 171, 675-677. [CrossRef] [PubMed]

2. Pecourt, J.L.; Peon, J.; Kohler, B. Ultrafast Internal Conversion of Electronically Excited RNA and DNA Nucleosides in Water. J. Am. Chem. Soc. 2000, 122, 9348-9349. [CrossRef]

3. Greco, N.J. Furan decorated nucleoside analogues as fluorescent probes: Synthesis, photophysical evaluation, and site-specific incorporation. Tetrahedron 2007, 63, 3515-3527. [CrossRef] [PubMed]

4. Hocek, M. Synthesis of Base-Modified 2'-Deoxyribonucleoside Triphosphates and Their Use in Enzymatic Synthesis of Modified DNA for Applications in Bioanalysis and Chemical Biology. J. Org. Chem. 2014, 79, 9914-9921. [CrossRef] 
5. Fin, A.; Rovira, A.R.; Hopkins, P.A.; Tor, Y. Emissive 5-Substituted Uridine Analogues. In Modified Nucleic Acids, Nucleic Acids and Molecular Biology 31; Nakatani, K., Tor, Y., Eds.; Springer International Publishing: New York, NY, USA, 2016; pp. 1-26.

6. Sinkeldam, R.W.; Wheat, A.J.; Boyaci, H.; Tor, Y. Emissive Nucleosides as Molecular Rotors. ChemPhysChem 2011, 12, 567-570. [CrossRef]

7. Greco, N.J.; Tor, Y. Simple fluorescent pyrimidine analogues detect the presence of DNA abasic sites. J. Am. Chem. Soc. 2005, 127, 10784-10785. [CrossRef]

8. Nielson, P.E.; Egholm, M.; Berg, R.; Buchardt, O. Sequence specific recognition of DNA by strand displacement with a thymine-substituted polyamide. Science 1991, 254, 1497-1500. [CrossRef]

9. Jensen, K.K.; Ørum, H.; Nielsen, P.E.; Nordén, B. Kinetics for Hybridization of Peptide Nucleic Acids (PNA) with DNA and RNA Studied with the BIAcore Technique. Biochemistry 1997, 36, 5072-5077. [CrossRef]

10. Vilaivan, T. Fluorogenic PNA probes. Beilstein J. Org. Chem. 2018, 14, 253-281. [CrossRef]

11. Wojciechowski, F.; Hudson, R.H.E. Nucleobase Modifications in Peptide Nucleic Acids. Curr. Top. Med. Chem. 2007, 7, 667-679. [CrossRef]

12. Wilhelmsson, L.M.; Holmen, A.; Lincoln, P.; Nielsen, P.E.; Norden, B. A Highly Fluorescent DNA Base Analogue that Forms Watson-Crick Base Pairs with Guanine. J. Am. Chem. Soc. 2001, 123, 2434-2435. [CrossRef] [PubMed]

13. Wojciechowski, F.; Hudson, R.H.E. Fluorescence and hybridization properties of peptide nucleic acid containing a substituted phenylpyrrolocytosine designed to engage guanine with an additional $\mathrm{H}$-bond. J. Am. Chem. Soc. 2008, 130, 12574-12575. [CrossRef] [PubMed]

14. Hudson, R.H.E.; Liu, Y.; Wojciechowski, F. Hydrophilic modifications in peptide nucleic acid-Synthesis and properties of PNA possessing 5-hydroxymethyluracil and 5-hydroxymethylcytosine. Can. J. Chem. 2007, 85, 302-312. [CrossRef]

15. Shinde, M.H.; Kshirsagar, U.A. A copper catalyzed multicomponent cascade redox reaction for the synthesis of quinazolinones. RSC Adv. 2016, 6, 52884-52887. [CrossRef]

16. Abbas, S.Y.; El-Bayouki, K.A.M.; Basyouni, W.M. Utilization of isatoic anhydride in the syntheses of various types of quinazoline and quinazolinone derivatives. Synth. Commun. 2016, 46, 993-1035. [CrossRef]

17. Han, B.; Yang, X.; Wang, C.; Bai, Y.; Pan, T.; Chen, X.; Yu, W. CuCl/DABCO/4-HO-TEMPO-Catalyzed Aerobic Oxidative Synthesis of 2-Substituted Quinazolines and $4 \mathrm{H} \mathrm{-3,1-Benzoxazines.} \mathrm{J.} \mathrm{Org.} \mathrm{Chem.} \mathrm{2012,} \mathrm{77,}$ 1136-1142. [CrossRef] [PubMed]

18. Mase, N.; Mizumori, T.; Tatemoto, Y. Aerobic copper/TEMPO-catalyzed oxidation of primary alcohols to aldehydes using a microbubble strategy to increase gas concentration in liquid phase reactions. Chem. Commun. 2011, 47, 2086-2088. [CrossRef]

19. Berlman, I.B. Empirical correlation between nuclear conformation and certain fluorescence and absorption characteristics of aromatic compounds. J. Phys. Chem. 1970, 74, 3085-3093. [CrossRef]

20. Hudson, R.H.E.; Heidari, A.; Martin-Chan, T.; Park, G.; Wisner, J.A. On the Necessity of Nucleobase Protection for 2-Thiouracil for Fmoc-Based Pseudo-Complementary Peptide Nucleic Acid Oligomer Synthesis. J. Org. Chem. 2019, 84, 13252-13261. [CrossRef]

21. Vergnaud, J.; Faugeras, P.A.; Chaleix, V.; Champavier, Y.; Zerrouki, R. Design of a new oligotriazole peptide nucleic acid analogue (oT-PNA). Tetrahedron Lett. 2011, 52, 6185-6189. [CrossRef]

22. Thomson, S.A.; Josey, J.A.; Cadilla, R.; Gaul, M.D.; Hassman, C.F.; Luzzio, M.J.; Pipe, A.J.; Reed, K.L.; Ricca, D.J.; Wiethe, R.W.; et al. Fmoc mediated synthesis of Peptide Nucleic Acids. Tetrahedron 1995, 51, 1-16. [CrossRef]

23. Hachmann, J.; Lebl, M. Alternative to Piperidine in Fmoc Solid-Phase Synthesis. J. Comb. Chem. 2006, 8, 149. [CrossRef] [PubMed]

Sample Availability: Samples of the compounds are not available from the authors. 